\title{
Diatoms from Lake Kushu: A pilot study to test the potential of a Late Quaternary palaeoenvironmental archive from Rebun Island (Hokkaido Region, Japan)
}

\author{
Mareike Schmidt $^{\mathrm{a}, *}$, Pavel E. Tarasov ${ }^{\mathrm{a}}$, Philipp Hoelzmann ${ }^{\mathrm{b}}$, Hanno Meyer $^{\mathrm{c}}$, Christian Leipe $^{\mathrm{a}}$ \\ a Institute of Geological Sciences, Paleontology, Freie Universität Berlin, Malteserstrasse 74-100, Building D, 12249 Berlin, Germany \\ ${ }^{\mathrm{b}}$ Institute of Geographical Sciences, Physical Geography, Freie Universität Berlin, Malteserstrasse 74-100, Building B, 12249 Berlin, Germany \\ 'Alfred Wegener Institute Helmholtz Centre for Polar and Marine Research, Research Unit Potsdam, Telegrafenberg A43, 14473 Potsdam, Germany
}

\section{A R T I C L E I N F O}

\section{Article history:}

Received 24 August 2015

Received in revised form 25 February 2016

Accepted 4 March 2016

Available online 4 March 2016

\section{Keywords:}

Diatoms

Late quaternary

Hokkaido

Marine transgression

Oxygen isotopes

Sediment geochemistry

\begin{abstract}
A B S T R A C T
Rebun Island is a key research area for the Baikal-Hokkaido Archaeology Project to better understand the dynamics of the Neolithic hunter-gatherers in the NW Pacific region. Hence, the ca. $19.5 \mathrm{~m}$ sediment core RK12 spanning the last ca. 16.6 cal. kyr BP was obtained from Lake Kushu. Our aim is to test its potential as a high-resolution multi-proxy archive. Here, we used diatoms to investigate the modern ecosystem of Lake Kushu and its surrounding area on Rebun Island and of Hime-numa Pond on Rishiri Island and selected core samples for comparison. Modern diatom and stable isotope analyses show well-mixed freshwater bodies with eutrophic, alkaline conditions. The fossil diatom and geochemical sediment analyses display three phases that represent major changes in the lake development: (i) a marshy phase (ca. 16.6-10 cal. kyr BP); (ii) a brackish water lagoon phase (ca. 10-6.6 cal. kyr BP); and (iii) a freshwater lake phase (since ca. 6.6 cal. kyr BP). This shows the major role of the post-glacial climate amelioration, global sea-level rise and marine transgression in the development of this landscape. Further analyses will provide a palaeolimnological record at (sub-)decadal resolution that will facilitate the interpretation of the hunter-gatherer dynamics.
\end{abstract}

(c) 2016 Elsevier Ltd. All rights reserved.

\section{Introduction}

An increasing number of archaeological sites of the huntergatherer cultures in the Hokkaido Region are being investigated (Weber et al., 2013 and references therein). Main research foci are to outline the differences between the Japanese and Okhotsk civilizations and the origin and geographical distribution of the Okhotsk people (Ohyi, 1975) that led to cultural heterogeneity (Moiseyev, 2008), which is also reported in characteristic pottery types (Deryugin, 2008).

The Baikal-Hokkaido Archaeology Project (BHAP) enlarged its study area from the Baikal Region (Siberia) towards the Hokkaido Region to improve the understanding of Holocene hunter-gatherers, their cultural dynamism, variability and lifestyle (Weber et al., 2013). In fact, the driving factors for cultural changes, e.g. environmental and climate changes or epidemic diseases, are not

\footnotetext{
* Corresponding author.

E-mail addresses: mareike.schmidt@fu-berlin.de (M. Schmidt), ptarasov@zedat. fu-berlin.de (P.E. Tarasov), phoe@zedat.fu-berlin.de (P. Hoelzmann), Hanno. Meyer@awi.de (H. Meyer), c.leipe@fu-berlin.de (C. Leipe).
}

fully understood. Because numerous remains of the Middle Jomon (5-4 cal. kyr BP), Late to Final Jomon (4-2.3 cal. kyr BP), Epi Jomon (2.3-1.3 cal. kyr BP), Okhotsk (1.5-0.8 cal. kyr BP), and Historic Ainu (0.7-0.1 cal. kyr BP; Müller et al., 2016) cultures that were recently found on Rebun Island, this area is of special interest for the BHAP research. So far there are 43 sites on Rebun Island, with the oldest residential sites dated to ca. 4.9-4.4 cal. kyr BP (see Müller et al., 2016 and references therein).

The need for a nearby high-resolution archive for reconstructing local and regional climate as well as environmental changes resulted in the Lake Kushu coring campaign in February 2012. Two parallel, overlapping sediment cores (RK12-01 and RK12-02) were taken in the central part of the ice-covered lake. The obtained ca. $19.5 \mathrm{~m}$ composite sediment core is a potentially high-resolution environmental archive, which will be investigated using a multiproxy approach that includes a ${ }^{14} \mathrm{C}$-inferred chronology, pollen, tephra, and geochemical analyses.

Various proxies have been used to reconstruct the Holocene climate and vegetation of Hokkaido and central Japan. Pollen-based reconstructions are among the most numerous during the last few decades, resulting in a number of articles concerning past 
vegetation or biome dynamics and its climatic and human-impact implications (e.g. Nakagawa et al., 2002, 2005; Gotanda et al., 2002, 2008; Igarashi et al., 2011; Tarasov et al., 2011; Hase et al., 2012; Igarashi, 2013; Leipe et al., 2013; Kigoshi et al., 2014).

Like terrestrial pollen, diatoms have been successfully used as a palaeoenvironmental proxy in Europe, North America and Africa (e.g. Gasse, 1986; Round et al., 1990; Smol and Stoermer, 2010). A considerable amount of studies has been published in local journals and in the Japanese language. Nevertheless, an increasing number of internationally accessible studies describing taxonomy, geographical distribution, and ecology of lacustrine, riverine, and coastal marine diatom taxa appeared during the last two decades. In Hokkaido, several water bodies have been analysed including Lake Akan (Tuji et al., 2003), Hii River (Ohtsuka, 2002), and Lake Tokotan (Sawai, 2002). Diatom-inferred environmental reconstructions for the Holocene were obtained from coastal plains including the Tokoro Region (Hamano et al., 1985), Akkeshi Estuary (Kumano et al., 1990a), Kushiro Moor (Ihira et al., 1985; Kumano et al., 1990b), and Kutcharo Lake (Kumano et al., 1984).

On Rebun Island, Kumano et al. (1990a) and Sato et al. (1998) analysed a $16.25 \mathrm{~m}$ sediment core spanning the last ca. 9000 years as suggested by the four ${ }^{14} \mathrm{C}$ dates given in their studies. Their core was obtained from the peat moor on the southern margin of Lake Kushu. These papers provide a relatively coarse-resolution diatom record with repeated occurrences of brackish-water environments, suggesting multiple phases of marine influence on Lake Kushu during the Holocene. Sato et al. (1998) mention taxonomic problems, which could be addressed by a high-resolution diatom analysis and would improve the understanding of the environmental history of Lake Kushu and its catchment. Until now, no study has focused on the modern diatom assemblages of Rebun Island and neighbouring Rishiri Island. Our paper is a pilot study and presents the first results on modern diatom assemblages from the Rebun and Rishiri islands in order to discuss the potential of fossil diatom assemblages as regional palaeoenvironmental indicators in a new sediment core from Lake Kushu representing the last 16,600 years.

\section{Study area}

\subsection{Environments}

Rebun and Rishiri islands are located $45 \mathrm{~km}$ and $19 \mathrm{~km}$, respectively, northwest off the coast of Hokkaido in the northeastern part of the Sea of Japan (Fig. 1a and b). The islands are - as with the entire Japanese Archipelago - located in a tectonically active zone with volcanism, earthquake and tsunami activities (e.g. Hashimoto, 1991; Kimura, 1997; Mandal et al., 2011). The formation of Rebun Island started with the subaqueous volcanic dome growth in the Cretaceous (Kimura, 1997; Goto and McPhie, 1998). Accordingly, the main units on Rebun Island exhibit Cretaceous volcanic rocks of the Rebun Group overlain by Late Miocene sedimentary formations with several basaltic to dacitic intrusions (Goto and McPhie, 1998). The highest point of the island is named Mount Rebun and reaches $490 \mathrm{~m}$ a.s.l. (Geospatial Information Authority of Japan, 2012). Rebun Island has an elongated shape and extends for ca. $20 \mathrm{~km}$ along the north-south axis and ca. $6 \mathrm{~km}$ along the east-west axis, spanning an area of ca. $82 \mathrm{~km}^{2}$ (Fig. 1d).

Rishiri Island, situated ca. $9 \mathrm{~km}$ southeast of Rebun Island (Fig. 1c), is composed of the main strato-volcano called Mount Rishiri, reaching $1721 \mathrm{~m}$ a.s.l. (Kuritani and Nakamura, 2006), and several small surrounding volcanoes attached to the main volcano (Mandal et al., 2011). Volcanic activity started ca. 200 kyr BP and deformed the Tertiary basement rocks (Mandal et al., 2011). The island has a more or less circular shape, measures ca. $14-18 \mathrm{~km}$ in diameter and spans an area of ca. $183 \mathrm{~km}^{2}$. Distance and area calculations for Rebun and Rishiri islands were performed based on ASTER GDEM 2 data (METI and NASA, 2011) applying a projected coordinate system (EPSG projection 2623) using ArcGIS v10.2 (ESRI, 2014).

The Tsushima Warm Current (TWC) flowing along the west coast of Hokkaido also influences Rebun and Rishiri islands. Its one branch, called the Soya Warm Current, flows through the Soya (or La Perouse) Strait and into the Sea of Okhotsk (Fig. 1a and b). The TWC affects the regional climate significantly (Igarashi, 2013), particularly during the cold season (November to May; see Leipe et al., 2013 for details and references therein) when the region is strongly influenced by the East Asian Winter Monsoon. Cold and dry air masses from Siberia passing over the relatively warm Sea of Japan collect its ascending moisture and heat resulting in heavy snowfalls in the western Hokkaido Region from November to April with highest amounts recorded in December (Igarashi, 2013; Leipe et al., 2013 and references therein). The Okhotsk High over the Sea of Okhotsk and the Ogasawara High in the northwestern subtropical Pacific control climatic conditions of the warm season. In years with a strong Okhotsk High, linked to the positive mode of the Winter North Atlantic Oscillation, summers are cool; by contrast, the Ogasawara High is connected to La Niña and results in relatively warm summers (Ogi et al., 2004; Igarashi et al., 2011; Igarashi, 2013). The following climatic data for Rebun and Rishiri islands were derived from a global highresolution interpolated (30 arc seconds or 1-km spatial resolution) climate surface dataset for land areas (Hijmans et al., 2005) averaged over a fifty-year (1950-2000) period and based on meteorological station data (Fig 2a). The mean monthly air temperature on Rebun Island varies from $-6.4{ }^{\circ} \mathrm{C}$ in January to $19.4{ }^{\circ} \mathrm{C}$ in August with a mean annual precipitation of $1102 \mathrm{~mm}$, with highest amounts falling from September $(131 \mathrm{~mm})$ to December (106 mm).

Nakagawa et al. (2002) and Leipe et al. (2013) described the predominant natural vegetation type (biome) of Rebun and Rishiri islands (as well as most of Hokkaido) as cool mixed forest. The vegetation on Rebun Island was severely impacted by human activities during the last century. The modern landscape is considerably deforested and Sasa spp. (bamboo grass from the Poaceae family) became widespread on the entire island (Müller et al., 2016). Patchy forests and shrubs occupy the river and spring valleys. The vegetation on Rishiri Island consists of a mixture of boreal conifers and cool-temperate broad-leaved trees (Igarashi, 2013). In the volcanic deposition area below $400 \mathrm{~m}$ a.s.l., Sasa spp. are very frequent as well, but their distribution decreases with higher altitude and under the forest cover.

\subsection{Hydrology}

Lake Kushu $\left(45^{\circ} 25^{\prime} 58^{\prime \prime} \mathrm{N}, 141^{\circ} 02^{\prime} 05^{\prime \prime} \mathrm{E}, 4 \mathrm{~m}\right.$ a.s.l.) is a relatively shallow coastal freshwater lake in the northern part of Rebun Island. The distance to Funadomari Bay is about $200 \mathrm{~m}$ (Fig. 1e). The lake is separated from the sea by sand barriers with dune ridges reaching up to $15 \mathrm{~m}$ a.s.l. that were formed by strong winter winds (Sato et al., 1998). The lake catchment spans an area of ca. $10 \mathrm{~km}^{2}$. The lake surface area covers about $0.53 \mathrm{~km}^{2}$ with a total shoreline length of $3.4 \mathrm{~km}$. The maximum water depth of $5.8 \mathrm{~m}$ occurs in the northern part of the lake and the average water depth is ca. $3.5 \mathrm{~m}$ (bathymetry data provided by T. Haraguchi, Osaka City University). Lake Kushu has two inflows and one outflow that connects with the sea. The major inflow, called Oshonnai River, enters the lake from the south. The second inflow is a small stream that reaches Lake Kushu from the southeast. The outflow in the north is canalised and flows through Funadomari town and into Funadomari Bay. The lake is surrounded by a ring of dense aquatic vegetation (mainly Phragmites and Typha) followed by a ring of trees 


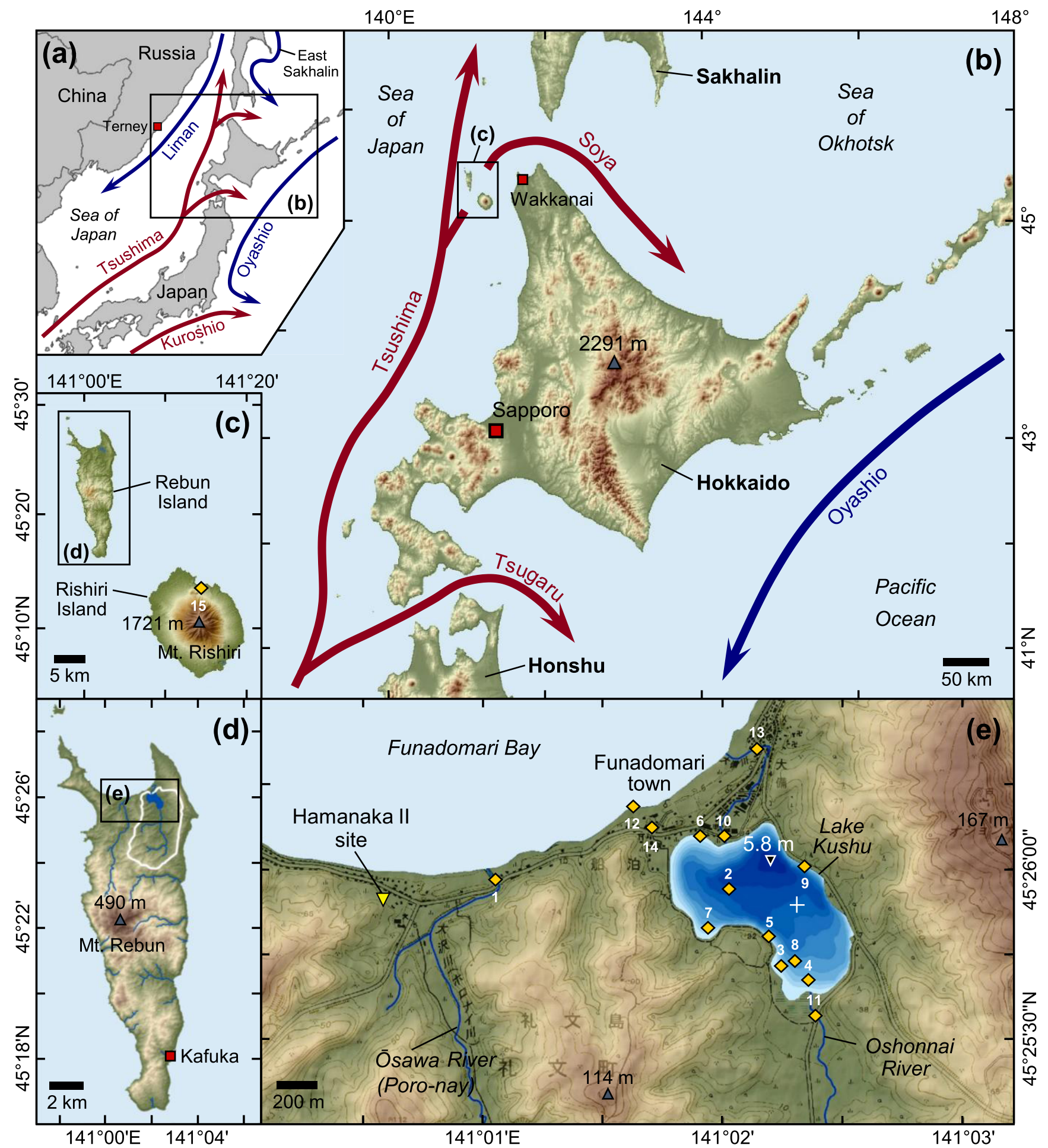

Fig. 1. Chart compilation showing (a) Japan and the location of Terney Climate Station; (b) Hokkaido, including the Tsushima, Tsugaru and Soya sea surface warm currents (red) and Oyashio cold current (blue); (c) outline of Rebun and Rishiri islands; (d) Rebun Island, including main rivers and location of Lake Kushu; (e) Lake Kushu. Isolines represent water depth in $0.5 \mathrm{~m}$ steps. Yellow triangle marks the archaeological Hamanaka 2 site, orange rhombuses indicate the sampling sites on Rebun and Rishiri islands (see Table 1 for details), white cross marks the location of the Kushu core RK12. Topographic maps are based on elevation Shuttle Radar Topography Mission (SRTM) V4.1 data (Reuter et al., 2007; Jarvis et al., 2008). Isolines for terrestrial area are drawn from a topographic map (Geospatial Information Authority of Japan, 2012). Bathymetry of Lake Kushu is based on survey data provided by T. Haraguchi (Osaka City University). (For interpretation of the references to colour in this figure legend, the reader is referred to the web version of this article.)

and shrubs, and extensive grasslands and meadows. The absence of large-scale agricultural activity and the dense vegetation cover substantially reduce soil erosion so that the accumulation in the lake reflects mainly lake bioproductivity and aeolian influx, with a minor impact from the inflowing rivers. The lake freezes from
December to April (Sato et al., 1998). The Ōsawa River flows west of the Lake Kushu catchment. It originates at Mt. Rebun and enters Funadomari Bay ca. $1.45 \mathrm{~km}$ west of the Lake Kushu outflow.

Hime-numa Pond ( $45^{\circ} 13^{\prime} 36^{\prime \prime} \mathrm{N}, 141^{\circ} 14^{\prime} 43^{\prime \prime} \mathrm{E}, 129 \mathrm{~m}$ a.s.l.) is a shallow circular artificial pond located in the northern part of 

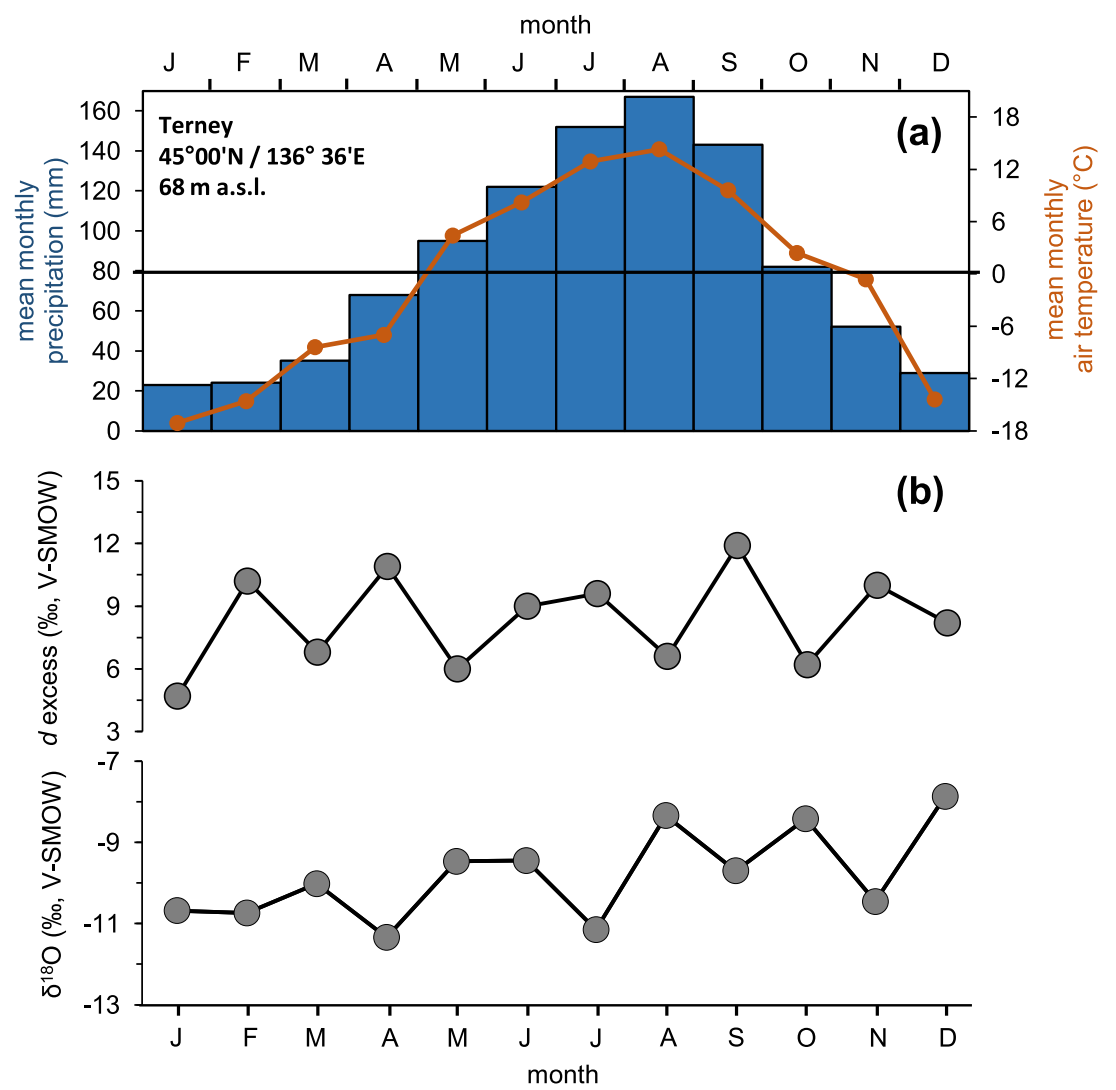

$\delta^{18} \mathrm{O}(\%$ vs. V-SMOW)

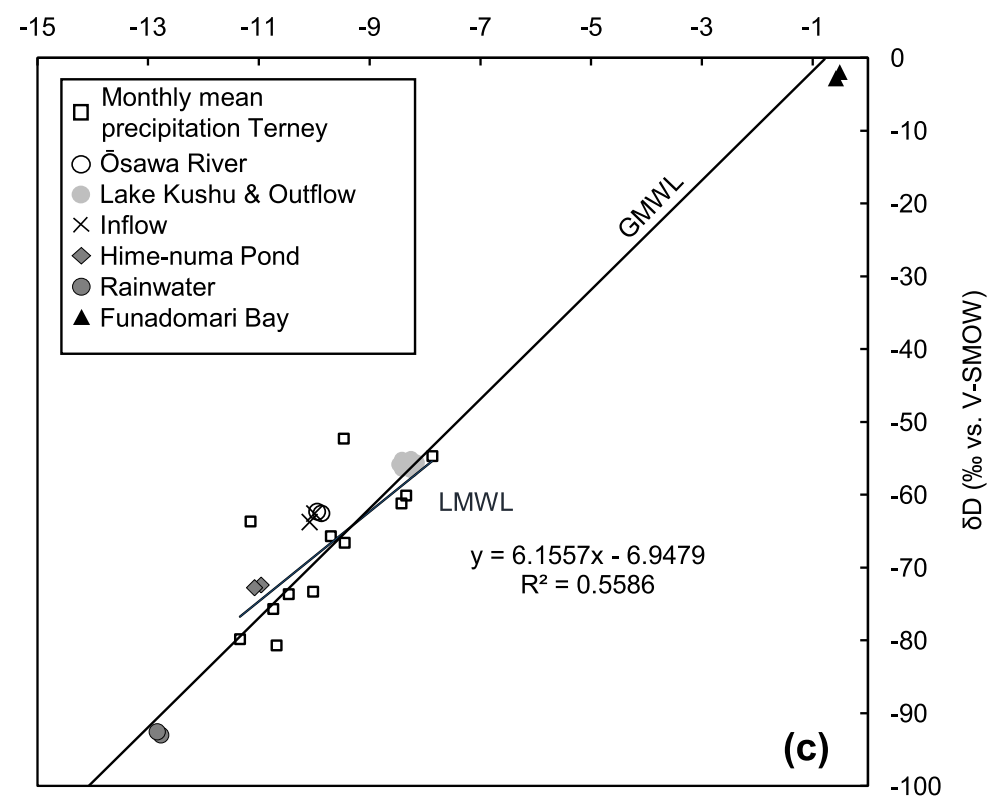

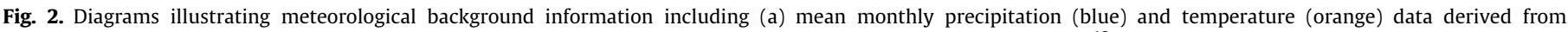

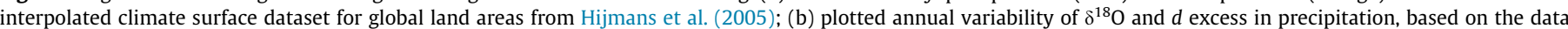

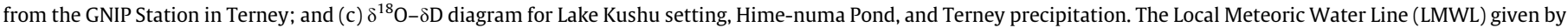

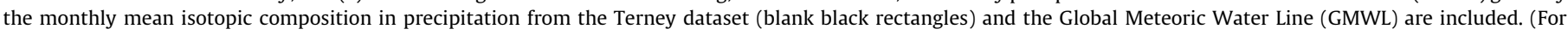
interpretation of the references to colour in this figure legend, the reader is referred to the web version of this article.)

Rishiri Island. The pond was created in 1917, when small swamps and springs were combined to form one larger waterbody. The freshwater pond has a shoreline of ca. $0.7 \mathrm{~km}$ (estimated during fieldwork) which corresponds to a surface area of $0.03 \mathrm{~km}^{2}$. The pond is fed by atmospheric precipitation (i.e. rain and snow) falling within its catchment area on the northern flanks of Mt. Rishiri. It has no major permanent surface inflow or outflow. The shore and lake bottom are partly stabilised with cement to control the 
shore, since the pond functions as a tourist site with a wooden trail constructed around it. The surrounding area is vegetated with trees and shrubs protecting the soil from erosion.

Unless otherwise stated, all given distances and areas in this chapter were calculated based on ASTER GDEM 2 data (METI and NASA, 2011) and a digitised and georeferenced topographic map (Geospatial Information Authority of Japan, 2012) applying a projected coordinate system (EPSG projection 2623) using ArcGIS v10.2 (ESRI, 2014).

\section{Material and methods}

\subsection{Modern diatom samples}

In August 2014, 15 modern diatom samples were collected. Most samples originate from Lake Kushu on Rebun Island (Fig. 1e, Table 1) and one sample represents Hime-numa Pond on Rishiri Island (Fig. 1c).

For a comprehensive overview of the diatom species living in Lake Kushu (including the inflow and outflow) we aimed at sampling different habitats. Therefore, surface lake sediments, surface waters and aquatic plants were collected. The surface lake sediments (1-2.4 m water depths) were collected in the near-shore area using a plastic cup fixed on a scaled telescope bar. Approximately, $30 \mathrm{ml}$ of material was taken from each location. The planktonic diatoms were sampled using a $65-\mu \mathrm{m}$ mesh size plankton net with a $100 \mathrm{ml}$ plastic tube mounted (Kalbe, 1980; Göke, 1993). The plankton net was hauled several times through the uppermost 10$20 \mathrm{~cm}$ of the water column. In total, ca. $250 \mathrm{ml}$ of each surface water sample were preserved in wide mouthed sterile plastic tubes with a screw top. To collect the epiphytic diatoms, the uppermost aquatic plant parts were removed and stored in a $500 \mathrm{ml}$ sterile wide mouthed plastic tube with a screw top. Following Battarbee et al. (2001), all samples were preserved with a few drops of Lugol's Iodine and stored in a cool and dark place.

\subsection{Water chemistry analysis}

Water variables such as surface water temperature, $\mathrm{pH}$, oxygen saturation, and electrical conductivity were measured with a WTW $340 \mathrm{i}$ portable meter. The samples for stable water isotope analysis - 11 surface water samples and one precipitation sample - were stored in $30 \mathrm{ml}$ narrow mouthed sterile plastic tubes, closed tightly with a screw top and stored in a cool and dark place. The stable oxygen and hydrogen isotope compositions were measured with a Finnigan MAT Delta-S mass spectrometer at the stable isotope laboratory of the Alfred Wegener Institute Helmholtz Centre for Polar and Marine Research, Research Unit Potsdam, Germany (see Meyer et al., 2000 for detailed explanation). The values are given as $\delta$-values in per mil difference to V-SMOW (Vienna Standard Mean Ocean Water). The standard deviation $(1 \sigma)$ is better than $\pm 0.8 \%$ and $\pm 0.1 \%$ or for $\delta \mathrm{D}$ and $\delta^{18} \mathrm{O}$, respectively.

\subsection{Fossil samples from Lake Kushu sediment: Choice and chronology}

Lake Kushu coring was performed on the ice-cover, in the central part of the lake at a water depth of ca. $4.5 \mathrm{~m}$ (the location is indicated with a white cross in Fig. 1e). Two parallel sediment cores RK12-01 and RK12-02 were drilled within a couple of metres distance using a hydro-pressure thin-walled piston corer. The overlap of the parallel cores allows for the sampling of a continuous ca. $19.5 \mathrm{~m}$ long composite sequence. The cores were transported to the Graduate School of Environmental Science at Hokkaido University in Sapporo and opened in April 2012 by splitting the core into two identical halves. Both cores were described and photographed in the laboratory and subsampled using the double L-channel (written as LL-channel) method (Nakagawa, 2007). The complete set of the plastic wrap-packed $1 \mathrm{~m}$ long LLchannel segments was sent to the Institute of Geological Sciences at the Freie Universität Berlin.

A set of 57 bulk samples (each representing $1 \mathrm{~cm}$ of the sediment core) was sent to the Poznan Radiocarbon Dating Laboratory for AMS dating. The obtained results of the ${ }^{14} \mathrm{C}$ dating allow the construction of an accurate age model, suggesting continuous sedimentation through the last ca. $16.6 \mathrm{kyr}$ (calibrated calendar ages before present, cal. yr BP are consistently used throughout the manuscript, unless specified otherwise, Fig. 3). A detailed description of the ${ }^{14} \mathrm{C}$ data and discussion of the calibration issues and age-depth model for the RK12 core will be presented in a separate paper (Müller et al., 2016).

On the material of the RK12 composite core from Lake Kushu a continuous diatom analysis at $1 \mathrm{~cm}$ intervals is planned. Before starting this time and labour consuming analysis the potential of the core's diatom assemblages for addressing different research questions such as marine impact and climate changes should be tested. Therefore, we selected and analysed ten fossil samples from throughout the core. Sample details such as corresponding ages and selected research foci that could be potentially addressed are presented in Fig. 4. To support interpretations made from the diatom record, sediment samples from selected depths were also geochemically analysed.

\subsection{Diatom analysis}

To remove the organic matter from the samples, $100 \mathrm{ml}$ of $10 \%$ hydrogen peroxide $\left(\mathrm{H}_{2} \mathrm{O}_{2}\right)$ were added and the beakers were placed on a hot plate at $80^{\circ} \mathrm{C}$ to accelerate the chemical reaction. After reaction had ceased, the chemical was washed out four times with $800 \mathrm{ml}$ distilled water.

The fossil sediment samples were treated using the standard techniques for diatom preparation according to Battarbee et al (2001). First, 37\% hydrochloric acid $(\mathrm{HCl})$ was added to the dried, weighted samples to remove the carbonates. Afterwards, $10 \%$ $\mathrm{H}_{2} \mathrm{O}_{2}$ was added to remove the organic residual. After each step, the chemicals were washed out with distilled water. After treatment, one drop of the solution (both for modern and fossil samples) was placed onto a cover slip, air-dried at room temperature and embedded into Naphrax ${ }^{\mathrm{TM}}$ (refractive index $=1.67$ ). The valves were counted using a Meiji Techno 4000 microscope, at $1000 \times$ magnification with immersion oil. When possible, 500 valves were counted in each sample. To avoid double counting, only fragments exceeding $50 \%$ of the total valve area were counted. To help with the identification of difficult taxa, photographs were taken with a Zeiss Supra 40VP scanning electron microscope (SEM).

Diatom identification was performed using the floras of Krammer and Lange-Bertalot (1997, 1999, 2000, 2004), Ohtsuka (2002), Kobayasi et al. (2006), Levkov (2009), Houk et al. (2010), Lee $(2011,2012)$ and Tanaka (2014). The taxonomical names follow the system on the website AlgaeBase (Guiry and Guiry, 2015). Bar diagrams of diatom percentages were plotted using Tilia ${ }^{\circledR}$ software (Grimm, 1991-2011).

For each sample, the individual taxon percentages were calculated based upon the total sum of counted valves taken as $100 \%$. Both, modern and fossil assemblage diagrams show taxa exceeding $5 \%$ individually. They are classified to pennate (mostly benthic) and centric (mostly planktonic) forms and further subdivided into freshwater and brackish/marine taxa. Species not exceeding $5 \%$ of the assemblages are summed up in the following groups: other benthic freshwater taxa, other benthic brackish/marine taxa, other planktonic freshwater taxa, and other planktonic brackish/marine taxa. The stack diagrams for $\mathrm{B} / \mathrm{P}$ (relationship of benthic to planktonic 
Table 1

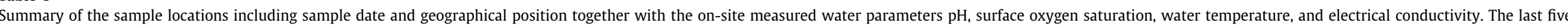
columns contain the results of the stable oxygen and hydrogen isotope analyses.

\begin{tabular}{|c|c|c|c|c|c|c|c|c|c|c|c|c|c|c|c|c|}
\hline ID RI-14- & Samples & Location name & Date [2014] & Longitude $[\mathrm{N}]$ & Latitude $[\mathrm{E}]$ & $\begin{array}{l}\text { Altitude } \\
\text { [m a.s.l.] }\end{array}$ & Water Depth [m] & $\mathrm{pH}$ & $\begin{array}{l}\text { Oxygen } \\
{[\%]}\end{array}$ & $\begin{array}{l}\text { Temp. } \\
{\left[{ }^{\circ} \mathrm{C}\right]}\end{array}$ & $\begin{array}{l}\text { Cond. } \\
{[\mathrm{S} / \mathrm{m}]}\end{array}$ & $\begin{array}{l}\delta^{18} \mathrm{O} \\
{[\% \text { vs. SMOW] }}\end{array}$ & $1 \sigma$ & $\begin{array}{l}\delta \mathrm{D} \\
{[\% \circ \text { vs. SMOW] }}\end{array}$ & $1 \sigma$ & $d$ excess \\
\hline $01 \mathrm{a}$ & Surface water & Ōsawa River & Aug-16 & 45.4330 & 141.0175 & 1 & 0.1 & 8.2 & 80 & 16.0 & 0.02 & -9.9 & 0.05 & -62.5 & 0.3 & 16.9 \\
\hline 01b & Water plant & Ōsawa River & Aug-16 & 45.4330 & 141.0175 & 1 & & & & & & & & & & \\
\hline $02 \mathrm{a}$ & Surface water & Kushu Lake & Aug-19 & 45.4322 & 141.0343 & 4 & 0.1 & 10.7 & 180 & 23.6 & 0.023 & -8.2 & 0.02 & -55.4 & 0.2 & 10.3 \\
\hline 03a & Surface water & Kushu Lake & Aug-19 & 45.4287 & 141.0378 & 4 & 0.1 & & & & & -8.4 & 0.05 & -55.9 & 0.3 & 11.5 \\
\hline 03b & Water plant & Kushu Lake & Aug-19 & 45.4287 & 141.0378 & 4 & & & & & & & & & & \\
\hline $04 a$ & Surface water & Kushu Lake & Aug-19 & 45.4277 & 141.0395 & 4 & 0.1 & 10.4 & 104 & 23.6 & 0.021 & -8.3 & 0.03 & -55.9 & 0.4 & 10.3 \\
\hline $05 a$ & Sediments & Kushu Lake & Aug-19 & 45.4302 & 141.0362 & 4 & 1.7 & & & & & & & & & \\
\hline 06a & Sediments & Kushu Lake & Aug-19 & 45.4351 & 141.0318 & 4 & 0.1 & & & & & & & & & \\
\hline $07 a$ & Surface water & Kushu Lake & Aug-21 & 45.4303 & 141.0325 & 4 & 0.1 & 9.2 & 78 & 22.6 & 0.02 & -8.3 & 0.03 & -56.1 & 0.3 & 10.3 \\
\hline 07b & Sediments & Kushu Lake & Aug-21 & 45.4303 & 141.0325 & 4 & 2.0 & & & & & & & & & \\
\hline $07 \mathrm{c}$ & Water plant & Kushu Lake & Aug-21 & 45.4303 & 141.0325 & 4 & & & & & & & & & & \\
\hline $08 \mathrm{a}$ & Sediments & Kushu Lake & Aug-21 & 45.4289 & 141.0378 & 4 & 2.4 & & & & & & & & & \\
\hline 09a & Surface water & Kushu Lake & Aug-21 & 45.4335 & 141.0389 & 4 & 0.1 & 10.7 & 160 & 23.7 & 0.021 & -8.3 & 0.03 & -56.1 & 0.3 & 10.3 \\
\hline 09b & Sediments & Kushu Lake & Aug-21 & 45.4335 & 141.0389 & 4 & 2.0 & & & & & & & & & \\
\hline $10 a$ & Surface water & Kushu Lake & Aug-21 & 45.4350 & 141.0335 & 4 & 0.1 & & & & & -8.4 & 0.02 & -55.7 & 0.3 & 11.2 \\
\hline $11 \mathrm{a}$ & Surface water & Oshonnai River & Aug-21 & 45.4261 & 141.0398 & 4 & 0.1 & 8.0 & 106 & 17.7 & 0.024 & -10.0 & 0.02 & -63.2 & 0.3 & 17.2 \\
\hline $12 \mathrm{a}$ & Surface water & Funadomari Bay & Aug-22 & 45.4364 & 141.0271 & 0 & 0.1 & 8.6 & 90 & 24.3 & 4.93 & -0.5 & 0.02 & -2.4 & 0.3 & 2.0 \\
\hline $12 \mathrm{~b}$ & Sediments & Funadomari Bay & Aug-22 & 45.4364 & 141.0271 & 0 & 0.4 & & & & & & & & & \\
\hline $12 \mathrm{c}$ & Water plant & Funadomari Bay & Aug-22 & 45.4364 & 141.0271 & 0 & & & & & & & & & & \\
\hline $13 a$ & Surface water & Kushu Outflow & Aug-22 & 45.4392 & 141.0357 & 3 & 0.1 & 9.6 & 63 & 24.4 & 0.02 & -8.4 & 0.04 & -56.1 & 0.4 & 11.4 \\
\hline $13 \mathrm{~b}$ & Water plant & Kushu Outflow & Aug-22 & 45.4392 & 141.0357 & 3 & & & & & & & & & & \\
\hline $14 a$ & Water & Rain water & Aug-24 & 45.4354 & 141.0280 & 8 & & & & & & -12.8 & 0.03 & -92.8 & 0.3 & 9.9 \\
\hline $15 a$ & Surface water & Hime-numa Pond & Aug-25 & 45.2269 & 141.2472 & 129 & 0.1 & 9.3 & 76 & 16.1 & 0.007 & -11.0 & 0.03 & -72.6 & 0.4 & 15.6 \\
\hline $15 \mathrm{~b}$ & Sediments & Hime-numa Pond & Aug-25 & 45.2269 & 141.2472 & 129 & 1.0 & & & & & & & & & \\
\hline
\end{tabular}




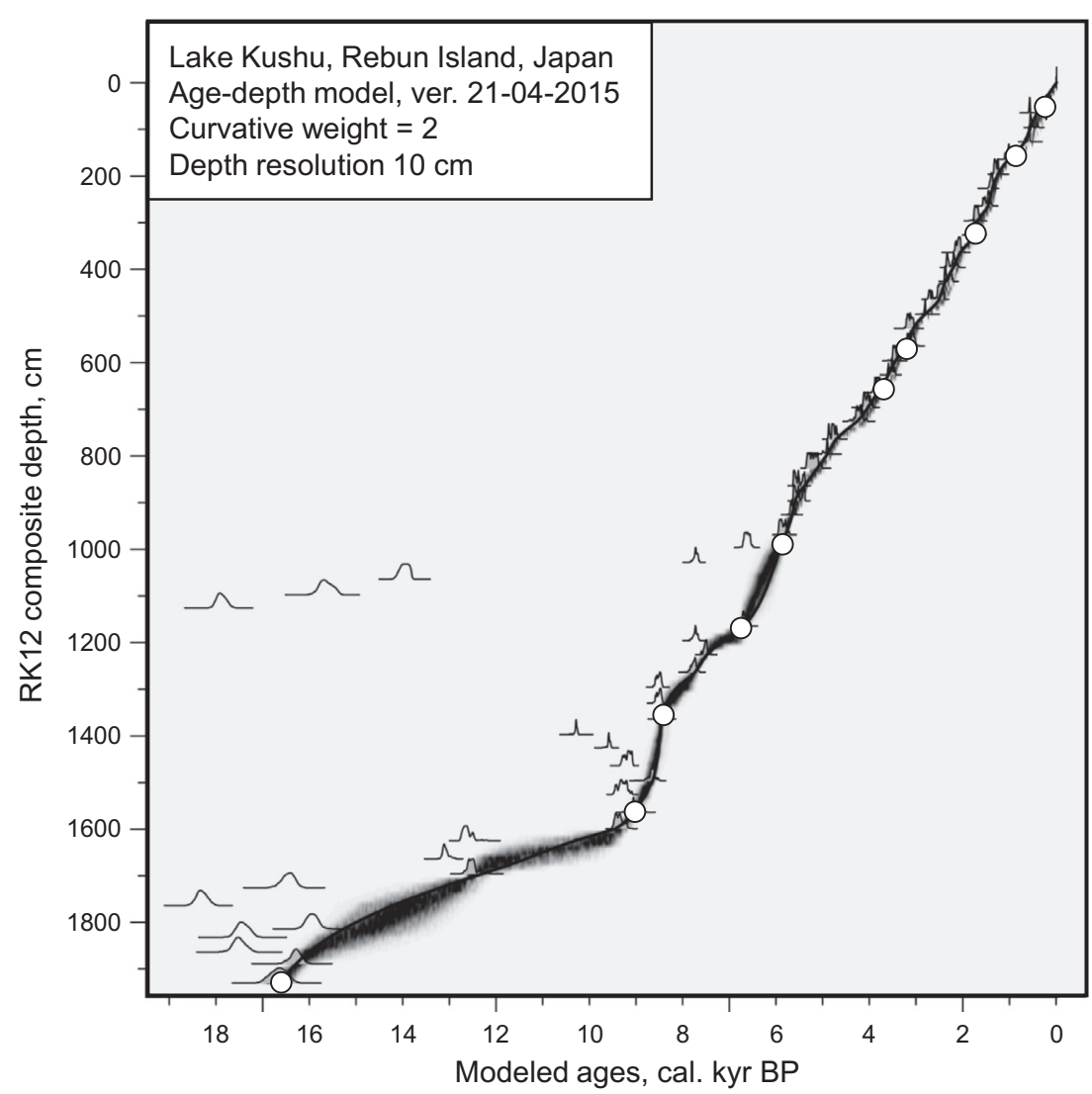

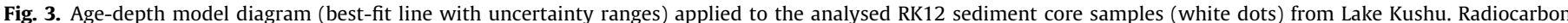

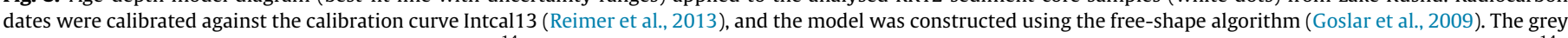

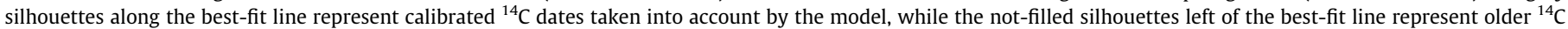
dates rejected by the model (redrawn after Müller et al., 2016).

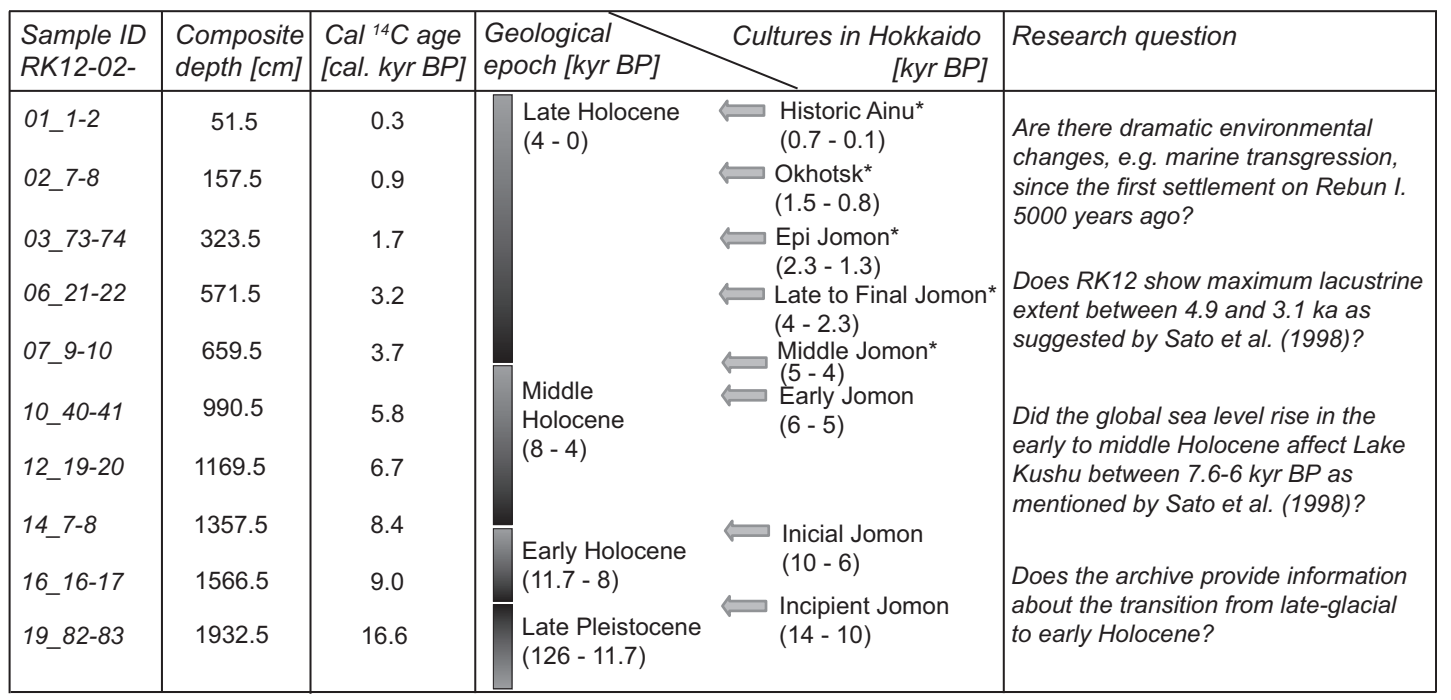

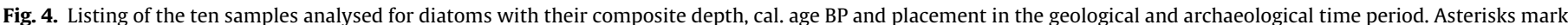
cultures of which remains were found on Rebun Island. Archaeological dates from Müller et al. (2016).

species, defined as $\left.\mathrm{B} / \mathrm{P}=\Sigma_{\text {benthic taxa }} / \Sigma_{\text {benthic+planktonic taxa }}\right)$, salinity, trophy and $\mathrm{pH}$ illustrate the sums of the ecological optima for each taxon based on data from the literature. The specific optima were coded with letters from $A$ to $\mathrm{E}$ for the $\mathrm{pH}$, from $\mathrm{A}$ to $\mathrm{F}$ for the trophy, from $A$ to $D$ for the salinity, and with $B$ or $P$ for the $B / P$, and added to the taxa information column in the Tilia $^{\circledR}$ spreadsheet for calculation.

\subsection{Geochemical analyses of core sediments}

\subsubsection{X-Ray fluorescence analysis (XRF)}

For elemental analyses of the bulk sediment a portable energydispersive X-Ray fluorescence spectrometer (P-EDXRF) Analyticon NITON XL3t equipped with a CCD-camera and a semi-conductor detector was used. The samples were grinded and homogenised 
with a vibrating cup mill. The resulting powder was dried for $2 \mathrm{~h}$ at $105^{\circ} \mathrm{C}$ and kept in a desiccator at room temperature. Ca. $4 \mathrm{~g}$ of the powdered samples were placed in plastic cups and sealed with Mylar foil $(0.4 \mu \mathrm{m})$. The prepared sample cups were placed on the P-EDXRF and measured for $120 \mathrm{sec}$ with different filters for the detection of specific elements with specifications (X-Ray source and Ag-anode) of $U_{\max } \cdot I_{\max }=2 \mathrm{~W}, U_{\max }=40 \mathrm{kV}$ and $I_{\max }=100 \mu \mathrm{A}$. Four filters were used with the following adjustments: (i) main measuring $30 \mathrm{~s}$ at $50 \mathrm{kV}$ with $40 \mu \mathrm{A}$, (ii) low measuring $30 \mathrm{~s}$ at $20 \mathrm{kV}$ with $100 \mu \mathrm{A}$, (iii) light measuring $30 \mathrm{~s}$ at $8 \mathrm{kV}$ with $250 \mu \mathrm{A}$, and (iv) high measuring $30 \mathrm{~s}$ at $50 \mathrm{kV}$ with $40 \mu \mathrm{A}$.

Before analysing the prepared samples the P-EDXRF was calibrated using two lacustrine sediments (Lynch, 1990) as certified reference material (CRM) LKSD-2 (lake sediment; Lot. Nr. 688) and LKSD-4 (lake sediment; Lot. Nr. 897). Only elements that show mean values larger than four times the $2 \sigma$ error of the measurements, i.e. aluminium ( $\mathrm{Al}$ ), calcium (Ca), iron ( $\mathrm{Fe})$, potassium $(\mathrm{K})$, rubidium $(\mathrm{Rb})$, sulphur $(\mathrm{S})$, silicon $(\mathrm{Si})$, strontium $(\mathrm{Sr})$, titanium (Ti), and zinc ( $\mathrm{Zn}$ ) were taken into account for the analyses (for further information see: Jenkins, 1999; De Vries and Vrebos, 2002). The calibration with the CRM was checked after every fifth sample measurement.

\subsubsection{ICP-OES analysis}

Sediment samples were analysed for major elements (Ca, Fe, K, magnesium (Mg), manganese (Mn), sodium (Na), phosphorus (P), $\mathrm{S}$, and $\mathrm{Sr}$ ) using an inductively coupled plasma optical emission spectrometer (ICP-OES Perkin Elmer Optima 2100DV) on the base of DIN EN 1346 (Anonymous, 2001). Dilutions of 0.5 up to $3.0 \mathrm{~g}$ of dry sediment were produced with aqua regia $(1.2 \mathrm{ml}$ of $65 \%$ nitric acid, $3.6 \mathrm{ml}$ of $3 \% \mathrm{HCl}$ and $0.5 \mathrm{ml}$ of water) in a microwave furnace (microwave digestion unit MLS-MEGA 90).

The solution was filtered into volumetric flasks $(50 \mathrm{ml})$ using glass funnels, fluted filters (particle retention 5-8 $\mu \mathrm{m}$, size $150 \mathrm{~mm}$ ), and bi-distilled water. The solution was kept in polyethylene (PE) flasks of $50 \mathrm{ml}$. For data quality control, blank reagents, duplicate dilutions and certified reference materials such as soils (NCS DC 73387, NCS 73325; with grain sizes of $<0.074 \mathrm{~mm}$ ), harbour sediment (LGC6156; with grain size $<200 \mu \mathrm{m}$ ), or lake sediments (LKSD-2; LKSD-4; with grain size $<80 \mu \mathrm{m}$; Lynch, 1990) were used. Relative standard deviations are as following: $\mathrm{Ca}=7 \%, \mathrm{Fe}=6 \%, \mathrm{~K}=7 \%, \mathrm{Mg}=5 \%, \mathrm{Mn}=6 \%$, $\mathrm{Na}=5 \%, \mathrm{P}=6 \%, \mathrm{~S}=7 \%, \mathrm{Sr}=6 \%$.

\section{Results}

\subsection{Modern diatom assemblages}

The results for the set of modern diatom samples are shown in Fig. 5. The analysed samples were rich in diatom valves. In total, 94 taxa could be identified of which eight species are planktonic and 86 are benthic. The species richness varies between 6 and 44 species per sample. The surface sediment samples from Lake Kushu being most diverse and the surface water samples from the inflow and Hime-numa Pond the least diverse. The most abundant taxa are illustrated with SEM photographs in Figs. 6 and 7.

The epiphytic diatom sample, taken from the Ōsawa River, consists of $84 \%$ monoraphid Cocconeis pediculus Ehrenberg. Lake Kushu samples are mainly composed of benthic species. The two planktonic species are Aulacoseira granulata (Ehrenberg) Simonsen reaching $31 \%$ of the assemblage in a surface sediment sample and Belonastrum berolinensis (Lemmermann) Bukhtiyarova with up to $19 \%$ in surface water and sediment samples from Lake Kushu. Dominant benthic species are Staurosirella pinnata (Ehrenberg) Williams \& Round reaching $79 \%$ in a surface sediment sample from
Lake Kushu and Nitzschia palea (Kützing) Smith with a maximum frequency of $46 \%$ in surface water samples. Amphora cf. indistincta Levkov reaches $25 \%$ in one surface sediment sample, whereas Epithemia adnata (Kützing) Brébisson reaches 25\% in one plant sample. Pseudostaurosira brevistriata (Grunow) Williams \& Round is abundant in a surface sediment sample with $22 \%$ and in one plant sample with $15 \%$.

The Lake Kushu inflow surface water sample contains the following seven species: Melosira varians Agardh (41\%), Navicula lanceolata Ehrenberg (19\%), Cocconeis neothumensis Krammer (13\%), Surirella brebissonii Krammer \& Lange-Bertalot (9.4\%), Meridion circulare var. constrictum (Ralfs) Van Heurck (9.4\%), Frustulia vulgaris (Thwaites) De Toni (3.1\%), and B. berolinensis (6.3\%). However, this sample shows a low valve concentration (32 valves) and must be excluded from the interpretation.

In the Lake Kushu outflow, the plant sample is dominated by Cocconeis placentula Ehrenberg attaining 46\%. The surface water sample is predominated by B. berolinensis (16\%), S. pinnata (20\%), and Fragilaria capucina var. vaucheriae (Kützing) Lange-Bertalot (14\%).

Regarding Hime-numa Pond, the surface water sample consists of $97 \%$ planktonic Aulacoseira ambigua (Grunow) Simonsen. The most frequent taxa in the surface sediment sample are $A$. ambigua (24\%), Stephanodiscus hantzschii Grunow (21\%) and A. cf. indistincta (23\%).

The valve concentration in the sediment, plant, and surface water samples from Funadomari Bay is too low ( $<50$ valve per sample) to obtain statistically reliable data. A few valves of Navicula directa (Smith) Ralfs, Proschkinia cf. bulnheimii (Grunow) Karayeva, Cocconeis sp., Amphora sp., and Psammodictyon sp. were observed. Therefore, the marine samples must be excluded from the discussion.

\subsection{Water analysis}

The results of the hydrochemical and stable oxygen and hydrogen isotope analyses are summarised in Table 1. In total, nine samples recording the $\mathrm{pH}$, surface oxygen saturation, temperature and electrical conductivity of the water were measured at different locations within Lake Kushu and once in the Ōsawa River, Oshonnai River, Lake Kushu outflow, Funadomari Bay, and Hime-numa Pond. Hydrogen and oxygen isotope analyses were performed on water samples from each water body and one precipitation sample. The water temperatures varied between 16.1 and $24.4^{\circ} \mathrm{C}$ showing lowest values in the Ōsawa River and Hime-numa Pond and highest values in the Kushu outflow. The $\mathrm{pH}$ varies between 8.0 in the Oshonnai River and 10.7 in Lake Kushu. All measured water bodies (excluding Funadomari Bay with $4.93 \mathrm{~S} / \mathrm{m}$ ) show freshwater conditions with a low to moderate conductivity $(70-240 \mu \mathrm{S} / \mathrm{cm})$. The lowest oxygen saturation of $63 \%$ was measured in the Lake Kushu outflow; highest values of $180 \%$ in the Lake Kushu surface water.

Fig. 2c presents a $\delta^{18} \mathrm{O}-\delta \mathrm{D}$ plot of all samples, related to the Global Meteoric Water Line (GMWL) which is defined as $\delta \mathrm{D}=8 \cdot \delta^{18} \mathrm{O}$ +10 , valid on a global scale for surface fresh water of non-closed basins without significant evaporation (Craig, 1961), as well as for precipitation (Rozanski et al., 1997). The analysed rivers and lakes are well separated in the co-isotope diagram, but close to the GMWL (Fig. 2c). The samples from Lake Kushu and its outflow show isotopically similar waters with $\delta^{18} \mathrm{O}_{\text {lake }}=-8.2 \%$ to $-8.4 \%$, $\delta \mathrm{D}_{\text {lake }}=-55.4 \%$ o to $-56.1 \%$ and $d$ excess lake $=+10.3 \%$ o to $+11.5 \%$. The Ōsawa and Oshonnai rivers both display a similar isotope composition with $\delta^{18} \mathrm{O}_{\text {river }}=-9.9 \%$ to $-10.0 \%, \quad \delta \mathrm{D}_{\text {river }}=$ $-62.5 \%$ to $-63.2 \%$ and $d$ excess $_{\text {river }}=+16.9 \%$ to $+17.2 \%$, whereas the stable isotope composition of Hime-numa Pond displays a slightly lighter isotopic composition $\left(\delta^{18} \mathrm{O}_{\text {pond }}=-11.0 \%\right.$, $\delta \mathrm{D}_{\text {pond }}=$ $-72.6 \%$ and $d$ excess pond $=+15.6 \%$ ) compared to those of Lake 


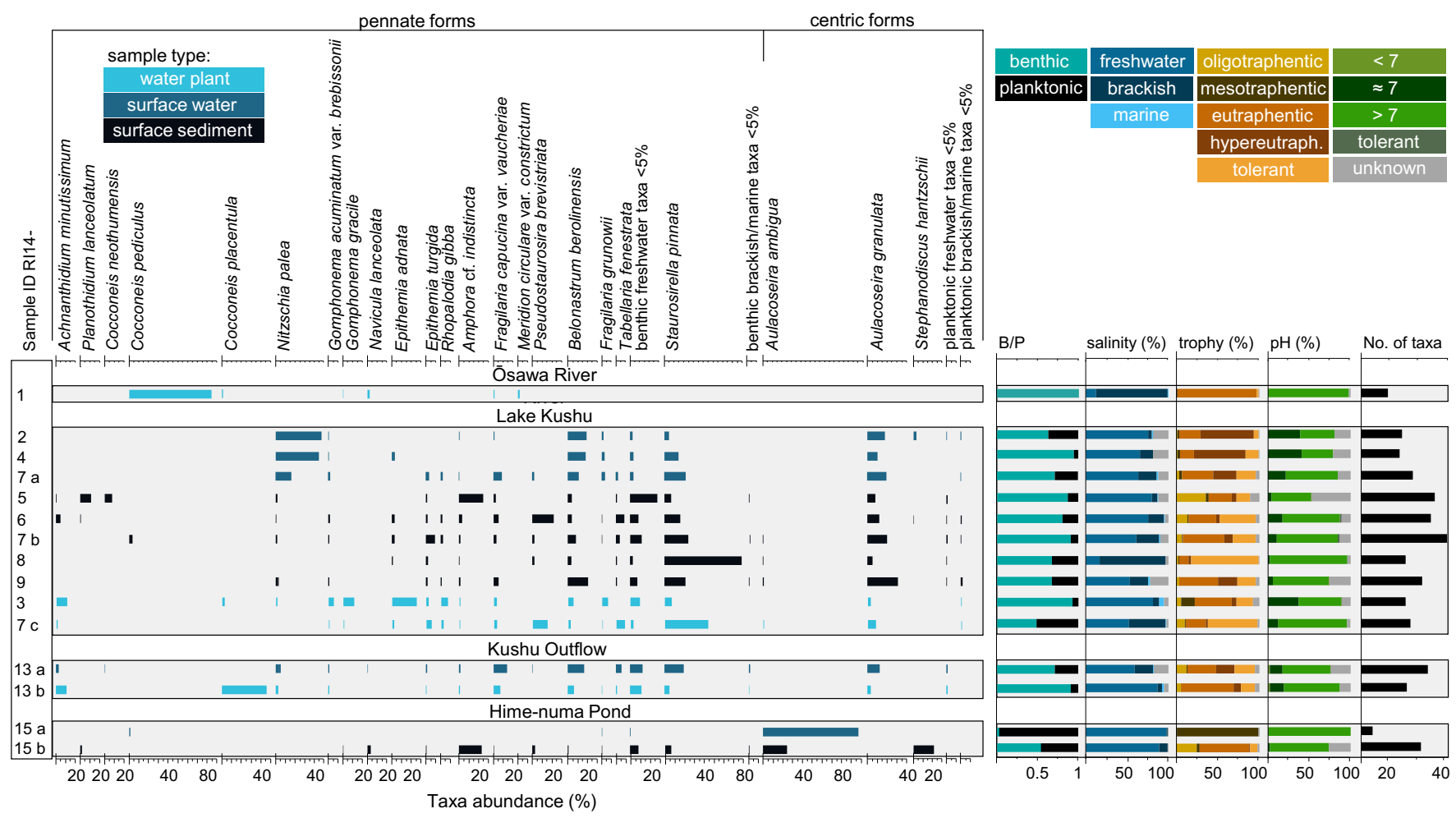

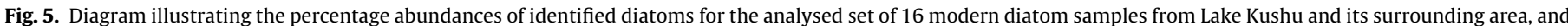

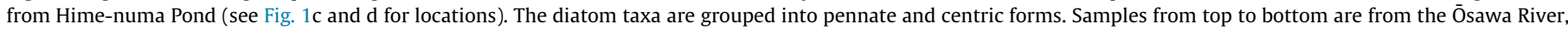

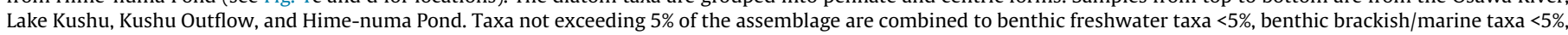

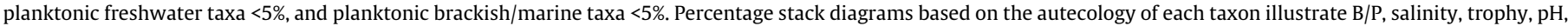
and No. of taxa.

Kushu. During rainfall on 24th August 2014 one precipitation sample was collected yielding $\delta^{18} \mathrm{O}_{\text {rain }}=-12.8 \%$ o, $\delta \mathrm{D}_{\text {rain }}=-92.8 \%$ and $d$ excess $_{\text {rain }}=+9.9 \%$. For comparison, monthly oxygen and hydrogen isotope composition of precipitation from the global network for isotopes in precipitation (GNIP) database (IAEA, 2015) of the nearby Russian meteorological station Terney (WMO code: 3190900 , $45^{\circ} 00^{\prime} \mathrm{N} 136^{\circ} 36^{\prime} \mathrm{E}, 68 \mathrm{~m}$ a.s.l., Fig. 1a) is shown in Fig. 2b. The mean annual isotopic precipitation composition in Terney with $\delta^{18} \mathrm{O}$ $=-9.8 \%$ is slightly lower than $\delta^{18} \mathrm{O}_{\text {lake }}$ water of $-8.3 \%$. The GNIP data are included in the $\delta^{18} \mathrm{O}-\delta \mathrm{D}$ diagram as well and were used to calculate the Terney Local Meteoric Water Line (LMWL) with $\delta \mathrm{D}=6.15 \cdot \delta^{18} \mathrm{O}-6.95$ on the base of the mean annual climate data over a five-year period (January 1996 to December 2000). As a consequence of the maritime location of Terney, the isotopic composition in precipitation (Fig. 2b) does not correlate with the measured air temperature (Fig. 2a).

\subsection{Fossil diatom assemblages}

The ten analysed fossil samples contain well-preserved diatom valves and in eight samples at least 500 valves were counted. In total, 102 taxa were identified of which 20 are planktonic and 82 benthic. However, most species are represented by low valve concentrations. The fossil assemblages reveal distinct changes along the RK12 core (Fig. 8).

The sample RK12-02-19_82-83 (1932.5 cm composite depth; in the following given as $\mathrm{cm}$; 444 counted valves) from the lower part of the core reveals the dominance of benthic Diploneis subovalis Cleve (78\%) and Pinnularia viridis (Nitzsch) Ehrenberg (15\%). No diatoms were found in the few samples of the core checked between 19 and $16.5 \mathrm{~m}$. The overlying sample (RK12-02-16_16$17 ; 1566.5 \mathrm{~cm})$ is dominated by the benthic freshwater species $P$. brevistriata (31\%) and Pseudostaurosira elliptica (Schumann) Edlund, Morales \& Spaulding (30\%). Marine Chaetoceros species are present with less than $5 \%$. Benthic brackish/marine taxa are represented by Pinnunavis yarrensis (Grunow) Okuno (3.8\%), Rhopalodia acuminata Krammer (3.3\%) and Mastogloia elliptica (Agardh) Cleve (0.3\%). The sample RK12-02-14_7-8 $(1357.5 \mathrm{~cm})$ contains the highest observed proportion of marine taxa (37.2\%), including Chaetoceros seiracanthus Gran (23\%), Chaetoceros radicans Schütt (7.3\%), Chaetoceros diadema (Ehrenberg) Gran (0.7\%) and Cyclotella choctawhatcheeana Prasad (6.2\%). Freshwater diatoms are represented by benthic Epithemia sorex Kützing and C. placentula (each 12\%). RK12-02-12_19-20 (1169.5 cm) shows minor percentages of marine taxa $(<5 \%)$. Chaetoceros spp. are absent in this sample, C. choctawhatcheeana reaches 5.2\%. Brackish M. elliptica comprises $6.5 \%$ of the assemblage. Benthic freshwater species reoccur with $P$. brevistriata (27\%), Rhopalodia gibba (Ehrenberg) Müller (14\%), E. sorex (6\%), Diatoma tenuis Agardh (5.2\%), and several benthic taxa each not exceeding $5 \%$ (grouped to other benthic freshwater and brackish/marine taxa $<5 \%$ ) composing in total $22 \%$. The sample of the middle part of the core (RK12-02-10_40-41; $990.5 \mathrm{~cm})$ exhibits a minor amount $(<10 \%)$ of benthic freshwater diatoms, and a high proportion of planktonic S. hantzschii (53\%), A. ambigua (15\%), A. granulata (11\%), and Asterionella formosa Hassall (8.6\%). The sample RK12-02-07_9-10 $(659.5 \mathrm{~cm})$ is mainly composed of planktonic diatoms (68\%) including A. ambigua (16\%), A. granulata (16\%), Aulacoseira islandica (Müller) Simonsen (18\%), and S. hantzschii (18\%). P. elliptica reaches $7.6 \%$ in this sample. RK12-02-06_21-22 $(571.5 \mathrm{~cm})$ shows almost twice as high abundances of the dominant taxa A. ambigua (33\%) and A. granulata (31\%) when compared to RK12-02-07_9-10. A. islandica still comprises $18 \%$. Marine $C$. choctawhatcheeana occurs with $5.4 \%$. Benthic freshwater diatoms play a minor role in both samples. 


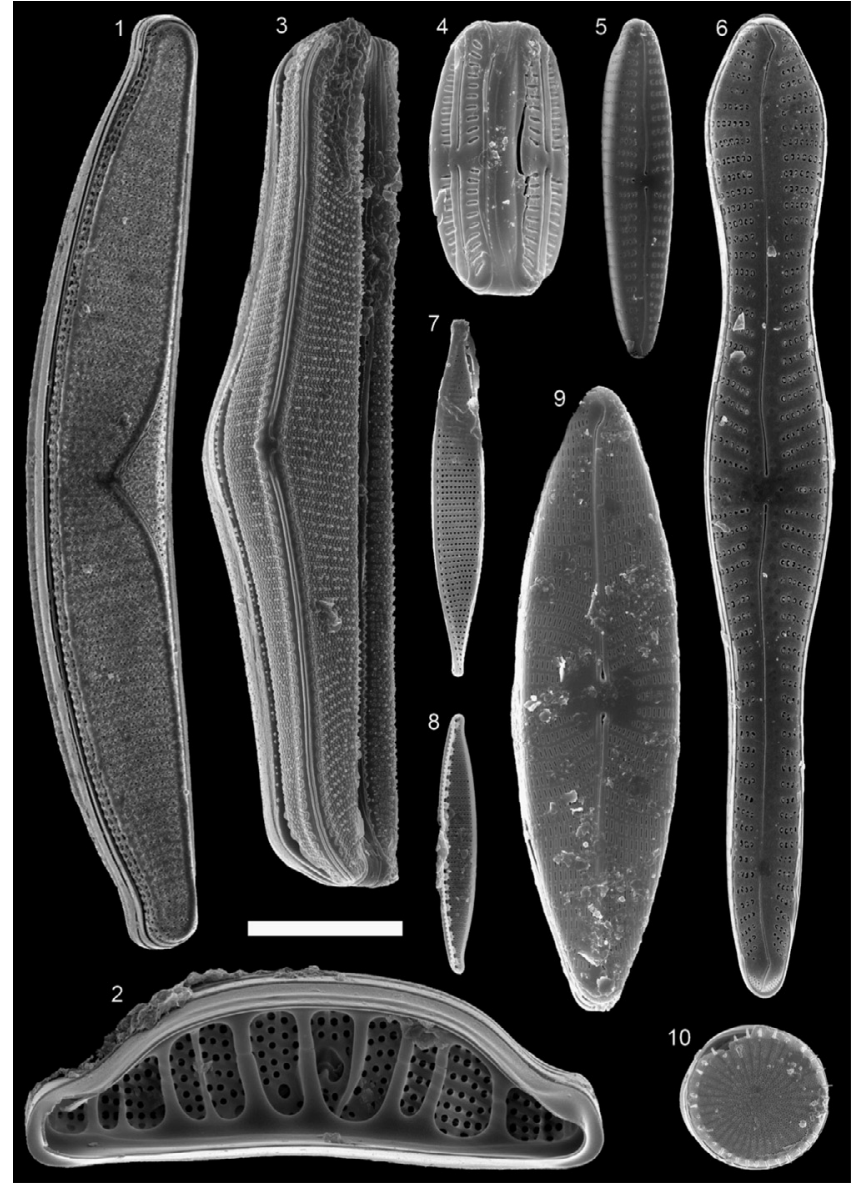

Fig. 6. SEM images of the modern diatoms exceeding $5 \%$ of the assemblage. 1 - Epithemia turgida, 2 - E. adnata, 3 - Rhopalodia gibba, 4 - Amphora cf. indistincta 5 - Gomphonema gracile, 6 - G. acuminata var. brebissonii, 7 and 8 - Nitzschia palea, 9 - Navicula lanceolata, 10 - Stephanodiscus hantzschii. Scale bar: $1=20 \mu \mathrm{m}$, $2-10=10 \mu \mathrm{m}$.

RK12-02-03_73-74 (323.5 cm) is dominated by A. granulata (65\%), A. ambigua (19\%), and $A$. islandica (9.7\%). In sample RK12-02-02_7-8 $(157.5 \mathrm{~cm})$ only 331 valves were counted. A. islandica is the dominant taxon reaching $56 \%$ of the assemblage. The benthic component $(18 \%)$ is composed of many species occurring at less than $5 \%$ of the assemblage which are grouped in the category other benthic freshwater taxa $<5 \%$. Gomphonema grovei var. lingulatum (Hustedt) Lange-Bertalot and P. elliptica occur with 6.9\% and 9.3\%, respectively. RK12-02-01_1-2 $(51.5 \mathrm{~cm})$ is also mainly composed of planktonic freshwater diatoms (86.8\%). A. ambigua reaches $64 \%$, A. granulata $15 \%$, and A. islandica $7.8 \%$, respectively. P. elliptica is the only abundant benthic species in this sample composing 9.3\%. Qualitative estimates for water parameters (B/P, salinity, trophy, and $\mathrm{pH}$ ) based on the autecology of identified diatoms are illustrated in Fig. 9a. The salinity stack diagram shows significant abundances of brackish/marine diatoms in sample RK12-0214_7-8 $(1357.5 \mathrm{~cm})$. The B/P diagram displays the shift from a benthos-dominated to a plankton-dominated assemblage in the RK12-02-10_40-41 (990.5 cm) sample. After this, the B/P remains low towards the top.

The trophy diagram shows several changes. The samples from the lower part of the core mainly consist of eutraphentic and trophy-tolerant species. In the sample RK12-02-10_40-41 the proportion of hypereutraphentic taxa increases (50\%). Oligotraphentic and mesotraphentic species reach $15 \%$ and $5 \%$, respectively. In the samples RK12-02-07_9-10 and RK12-02-06_21-22 mesotraphentic

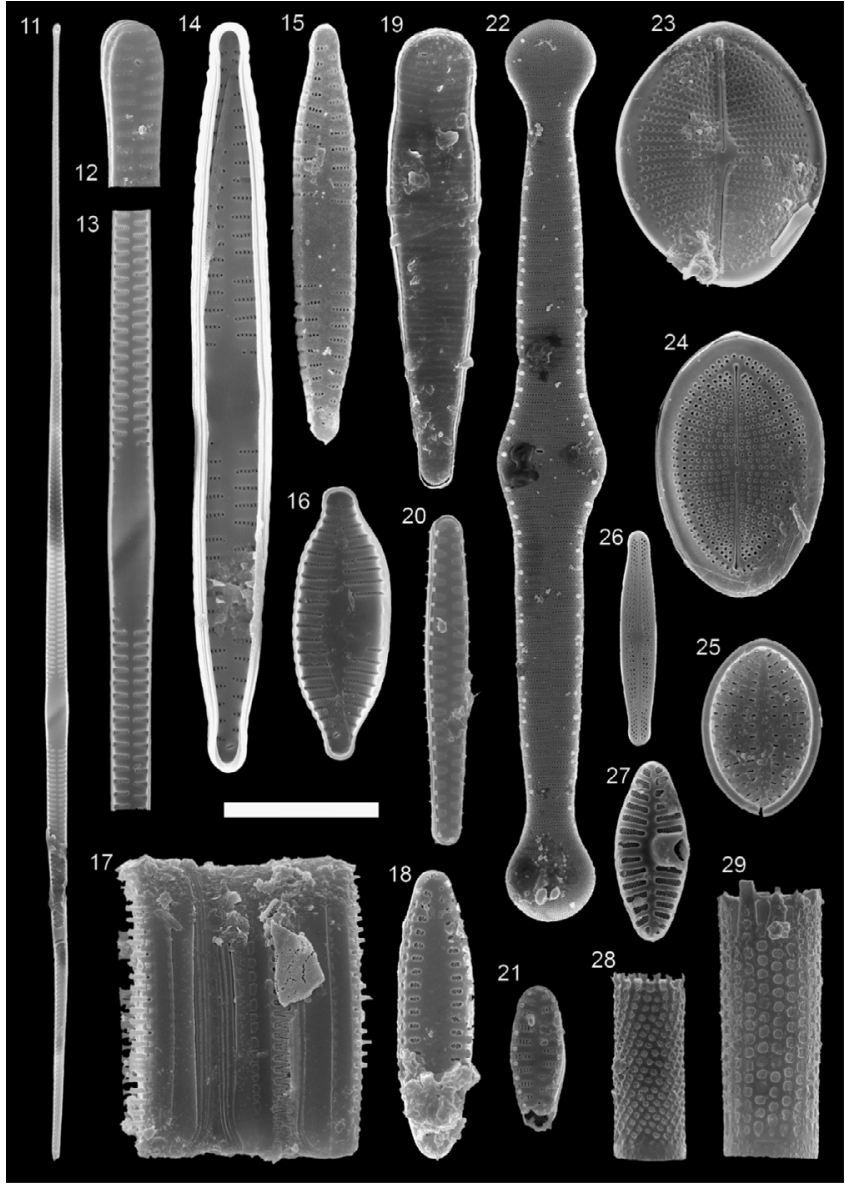

Fig. 7. SEM images continued. 11-13 - Fragilaria grunowii, 14-16 - Fragilaria capucina var. vaucheriae, 17 and 18 - Pseudostaurosira brevistriata, 19 - Meridion circulare var. constrictum, 20 - Belonastrum berolinensis, 21 - Staurosirella pinnata, 22 - Tabellaria fenestrata, 23 - Cocconeis pediculus, 24 - C. placentula, 25 - C. neothumensis, 26 - Achnanthidium minutissimum, 27 - Planothidium lanceolatum, 28 - Aulacoseira ambigua, 29 - A. granulata. Scale bar: $11=20 \mu \mathrm{m}, 12-29=10 \mu \mathrm{m}$.

species occur ( $16 \%$ and $35 \%$, respectively) and the proportion of hypereutraphentic species decreases. RK12-02-02_7-8 is characterised by the highest abundance of tolerant diatoms. The uppermost sample (RK12-02-01_1-2) contains 60\% mesotraphentic diatoms.

The reconstructed $\mathrm{pH}$ indicates alkaline conditions throughout the section. However, the abundance of diatoms preferring lower $\mathrm{pH}$ (around 7) represents 25-60\% in the samples RK12-02-07_910, RK12-02-06_21-22 and RK12-02-02_7-8. Two samples (RK1202-10_40-41 and RK12-02-03_73-74) contain highest proportions (12-15\%) of diatoms which prefer a pH below 7.

\subsection{Geochemical (P-EDXRF and ICP-OES) analysis of the core sediment}

20 sediment samples were geochemically analysed from the RK12 core between 1933.5 and $52.5 \mathrm{~cm}$. For all samples the main components are $\mathrm{Si}, \mathrm{Fe}$ and $\mathrm{Al}$ as the organic fraction has not been determined yet. Si values vary between $14.0 \%$ and $29.3 \%$ with a mean of $20.7 \%$. Fe values range between $2.3 \%$ and $5.3 \%$ (mean $3.7 \%$ ) whereas $\mathrm{Al}$ exhibits values between $1.8 \%$ and $4.5 \%$ (mean $3.4 \%$ ). However, we focus here on elements and elemental ratios that may reflect marine influences such as $\mathrm{K}, \mathrm{Na}, \mathrm{P}, \mathrm{S}, \mathrm{Si}, \mathrm{Ti}$, $\mathrm{Sr} / \mathrm{Ca}$, and $\mathrm{Mg} / \mathrm{Ca}$ (Fig. 9b).

The basal three samples $(1933.5-1701.5 \mathrm{~cm})$ show strong variations in all above listed elements. For example Si (14.3-23.5\%), 


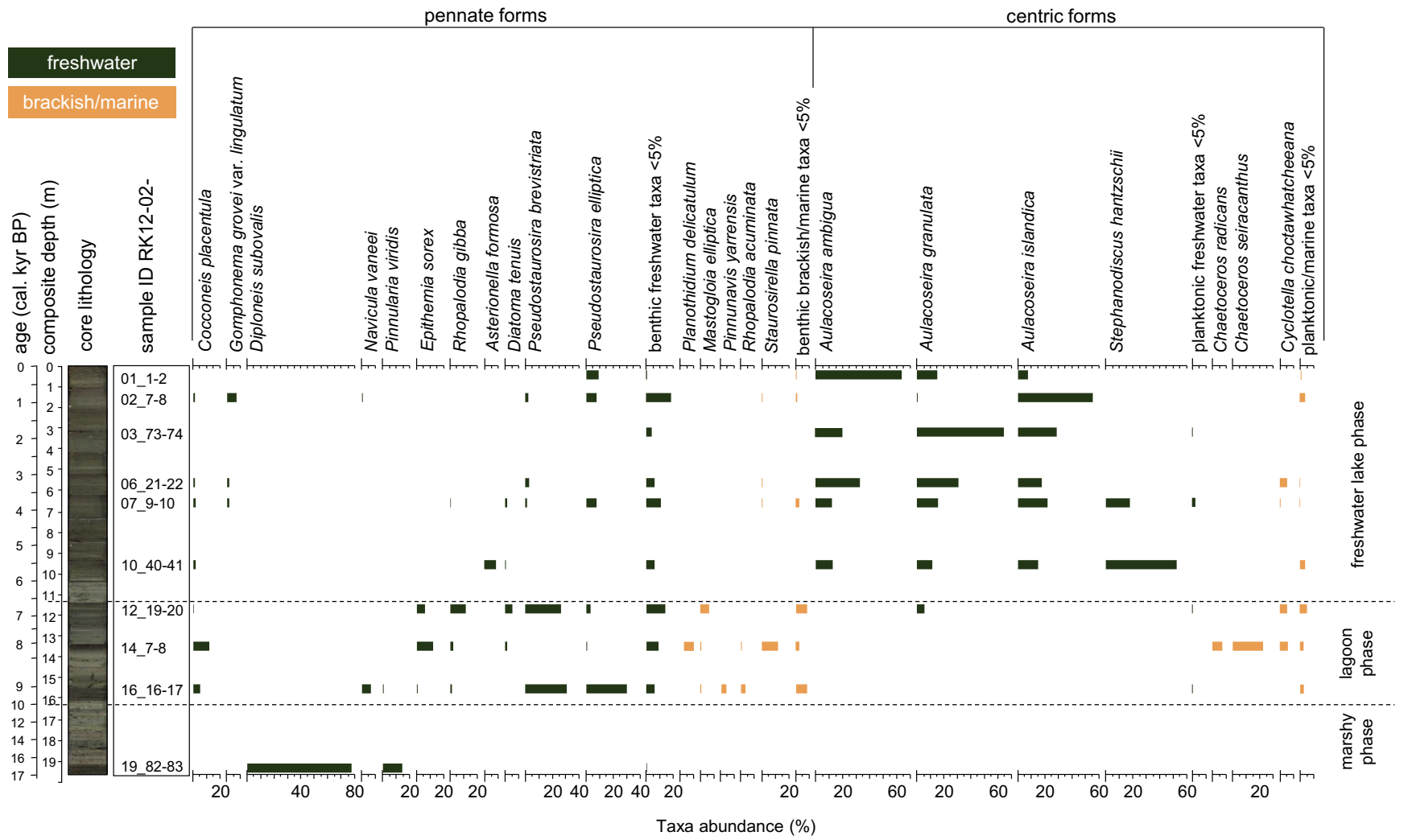

Fig. 8. Diatom assemblage diagram representing the percentage abundances of identified diatoms for the ten analysed RK12 core samples (location is indicated by a white cross in Fig. 1e). The diatom taxa are grouped in pennate and centric forms. Freshwater taxa are coloured in dark green, brackish/marine taxa in orange. Taxa not exceeding $5 \%$ of the assemblages are grouped into benthic freshwater taxa $<5 \%$, benthic brackish/marine taxa $<5 \%$, planktonic freshwater taxa $<5 \%$, and planktonic brackish/marine taxa $<5 \%$. (For interpretation of the references to colour in this figure legend, the reader is referred to the web version of this article.)

(a)
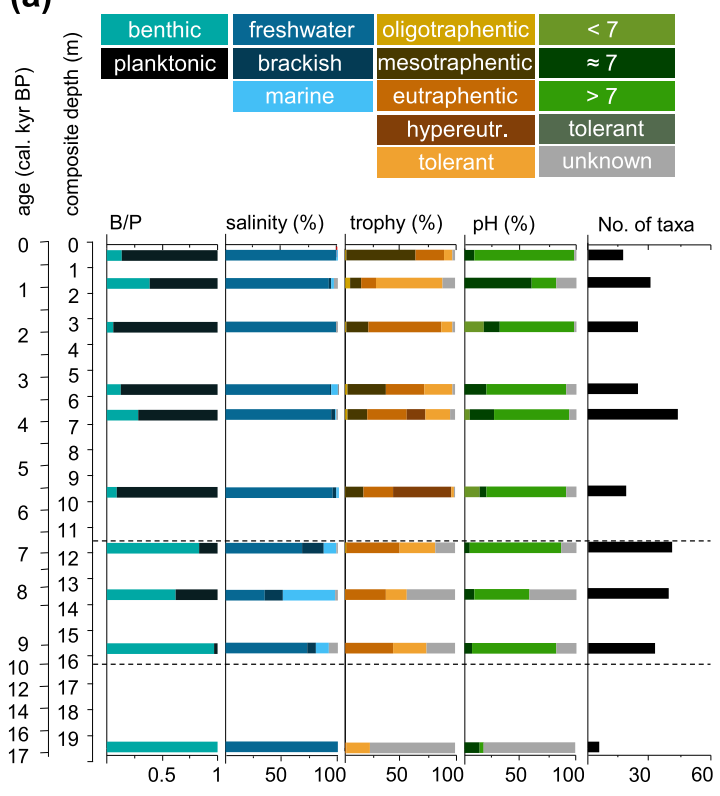

(b)

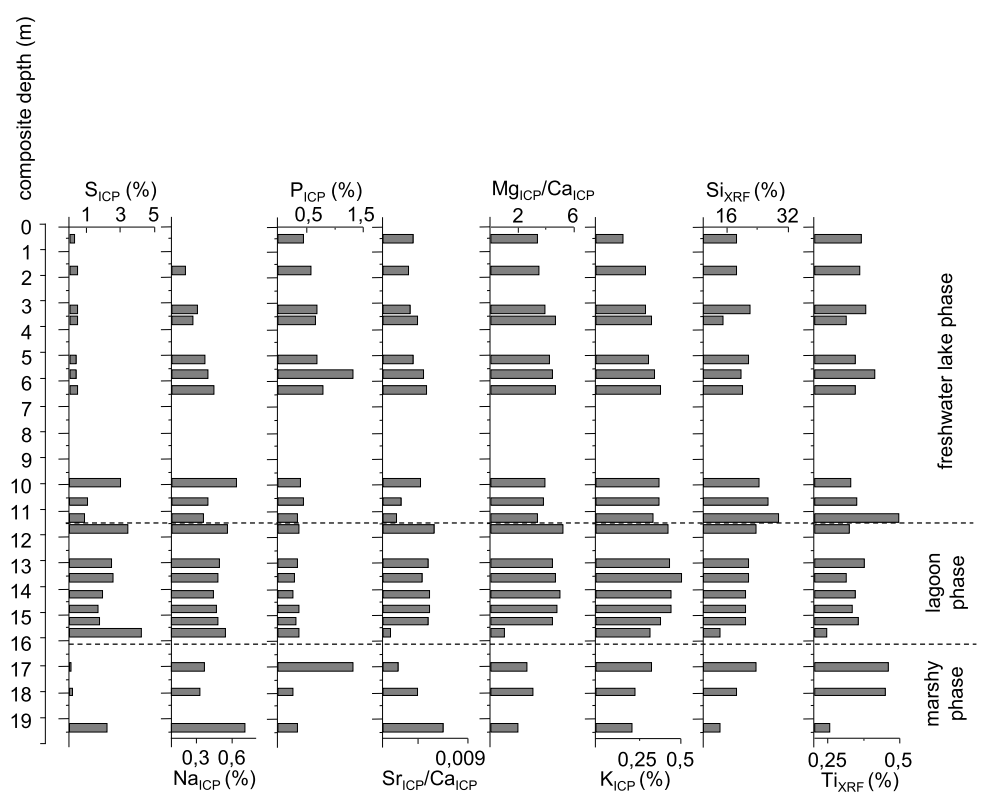

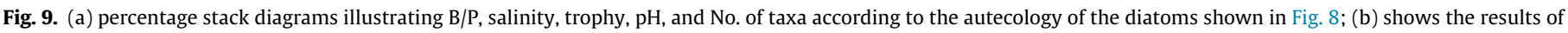
the XRF and ICP - OES analyses.

Ti (0.25-0.46\%), S (<0.1-2.16\%), Na (0.37-0.7\%), and P (0.35-1.30\%) show heterogenic patterns within this section.

Between 1567.5 and $1170.5 \mathrm{~cm}$ seven sediment samples were analysed. All elements exhibit values within a narrow range. This is most obvious for $\mathrm{Na}, \mathrm{P}$ and $\mathrm{S}$. Whereas $\mathrm{S}$ shows elevated values between 1.7 to $4.2 \%$, lowest and uniform $P$ values $(0.25-0.37 \%$; mean $0.32 \%$ ) represent this section. Also Na exhibits slightly elevated values within a narrow range (0.44-0.55\%; mean $0.49 \%$ ). 
When the lowermost sample at $1567.5 \mathrm{~cm}$ is not considered, the same feature is observed for $\mathrm{Si}$ (20.6-23.6\%; mean 20.7\%) and $\mathrm{Ti}$ (0.31-0.37\%; mean $0.34 \%$ ) as well as for the elemental ratios $\mathrm{Sr} /$ Ca (0.0063-0.007; mean 0.0066), and $\mathrm{Mg} / \mathrm{Ca}$ (4.39-5.13; mean 4.67).

Three samples were analysed from the interval between 1127.5 and $990.5 \mathrm{~cm}$. These samples show slightly different element concentrations, which is most obvious for $\mathrm{S}, \mathrm{Sr} / \mathrm{Ca}, \mathrm{Mg} / \mathrm{Ca}, \mathrm{Si}$, and $\mathrm{Ti}$. For S (0.84-2.95\%), Sr/Ca (0.0048-0.0061) and $\mathrm{Mg} / \mathrm{Ca}(3.33-3.88)$ the values are lower, whereas $\mathrm{Ti}(0.33-0.50 \%)$ and $\mathrm{Si}(24.4-$ 29.3\%) show higher concentrations.

The interval between 634.5 and $52.5 \mathrm{~cm}$ is represented by seven samples that show similar values as the previously described section for the elemental ratios $\mathrm{Sr} / \mathrm{Ca}$ and $\mathrm{Mg} / \mathrm{Ca}$ as well as for the elemental concentrations of $\mathrm{K}, \mathrm{Si}$, and Ti. However, for this part of the core the S values are low $(0.26-0.43 \%$; mean $0.37 \%)$ and $\mathrm{Na}$ decreases towards the core top (from $0.44 \%$ to $0.11 \%$ ). P also decreases towards the top but shows much higher values (0.451.32\%) when compared to samples between 1567.5 and $990.5 \mathrm{~cm}$.

\section{Interpretation and discussion}

\subsection{Modern lake basin}

Geographically, Lake Kushu is situated in the temperate climate zone. It is dimictic with a freezing period from December to April (Sato et al., 1998), spring and autumn circulation and summer stagnation (Schönborn and Risse-Buhl, 2013). The shallow basin morphology represents a mature lake stage defined by a high ratio of $z_{\mathrm{a}} / z_{\mathrm{m}}$ (i.e. $0.6 ; z_{\mathrm{a}}=3.5 \mathrm{~m} / \mathrm{z}_{\mathrm{m}}=5.8 \mathrm{~m}$ ), where $z_{\mathrm{a}}$ indicates the average depth of the lake and $z_{\mathrm{m}}$ represents its maximal depth. The low water depth results in the absence of a tropholytic zone that leads to photosynthetic activity in all parts of the lake causing eutrophication (Schönborn and Risse-Buhl, 2013) and massive algal blooms in summer, which we could observe during fieldwork in August 2014. The present influence of human activities on the lake seems minor since there are very limited agricultural activities and cattle breeding on Rebun Island. We observed sewage disposal into the outflow but no drainage directly into Lake Kushu. However, we cannot exclude sewage disposal into the lake. Locals reported that the lake is not being used for any leisure activities like fishing, swimming or other water sports as a result of the eutrophic to hypereutrophic conditions.

Its flat basin topography suggests that Lake Kushu has reached a mature stage. The high bioproductivity in the warm season leads to high accumulation rates of organic-rich sediments. However, the reported deforestation in the first half of the $20^{\text {th }}$ century (see Müller et al., 2016) might have led to soil destabilizations and an increase of the nutrient inflow from the catchment area.

The $\mathrm{pH}$ measured near the water surface varied between 9.2 and 10.7 (Table 1). The high $\mathrm{pH}$ can be explained by the high photosynthetic activity of the algal bloom which consumes the near surface $\mathrm{CO}_{2}$ causing higher surface water $\mathrm{pH}$ during summer stagnation (Schönborn and Risse-Buhl, 2013). Coherently to the photosynthesis-induced decrease of $\mathrm{CO}_{2}$, the oxygen saturation experiences a significant increase resulting in values between $78 \%$ and $180 \%$. The measured stable oxygen and hydrogen isotope composition in the surface water samples plot close to the GMWL and LMWL (Fig. 2c) indicating the absence of major evaporation processes. The lake samples show very similar stable isotope values and represent a well-mixed water body with an average composition of $\delta^{18} \mathrm{O}_{\text {lake }}=-8.3 \%, \quad \delta \mathrm{D}_{\text {lake }}=-55.8 \%$ and $d$ excess $_{\text {lake }}=+10.9 \%$. These results correlate with the typhoon season that lasts seven months from May to November. Typhoons bring high amounts of precipitation and storms affecting the studied area regularly (Terry and Feng, 2010). Two weeks prior to our sampling campaign, the typhoon named 'Halong' (formed on 27th July 2014, dissipated on 15th August 2014) crossed the Hokkaido Region from south to north, affecting Rebun and Rishiri islands. The isotope composition of Lake Kushu is similar to that of the summer precipitation of the nearby meteorological station Terney (Fig. 2b and c) indicating that the shallow lake is completely recharged in summer. However, due to the maritime location of Terney the isotopic composition in precipitation shows minor variations and the absence of annual trends.

During the observation period, the eutrophic, or at time hypereutrophic, lake showed a massive green algal bloom, giving the lake a green colour and a low water transparency $(<10 \mathrm{~cm})$. The flourishing green algae replace the planktonic diatom species as shown by a very low valve concentration in surface water samples (ca. 500 valves per slide, $\varnothing 18 \mathrm{~mm}$ ).

Within the Lake Kushu samples, Nitzschia palea is mainly present in the planktonic samples representing $17-46 \%$. N. palea is a widely distributed taxon known from lotic and lentic freshwater habitats, tolerant of heavy organic pollution (Trobajo et al., 2009). Krammer and Lange-Bertalot (1999) described N. palea as a common taxon, which occurs frequently within the plankton. Planktonic Aulacoseira granulata, which is frequent as well, is described from eutrophic habitats (Van Dam et al., 1994; Gómez et al., 1995; Krammer and Lange-Bertalot, 2000). The presence of A. granulata, which needs turbulence of the water (Gómez et al., 1995), can be associated with the typhoon season in summer. Staurosirella pinnata and $B$. berolinensis occur in the surface water samples as well as in the surface sediment and plant samples (Fig. 8). Van Dam et al. (1994) reported S. pinnata as an oligo- to eutraphentic taxon. Krammer and Lange-Bertalot (2000) mentioned the difficulty of the named-by-synonym Fragilaria pinnata-taxon (see also Morales et al., 2013) and suggest $S$. pinnata to be a very tolerant species concerning $\mathrm{pH}$ ( $<7$ up to 9.3) and trophic level (oligo- to eutrophic; Van Dam et al., 1994). B. berolinensis is a planktonic colonial form associated with alkaline, eutrophic (Van Dam et al., 1994) unless hypereutrophic conditions (Bradshaw et al., 2002) which fits very well with the measured water parameters.

Interestingly, the assemblages of the plant, surface water, and sediment samples are much more similar to each other than expected. The B/P values (Fig. 9a) display a high similarity between the samples, supporting the assumption of a well-mixed water body.

The analysed water parameters from Hime-numa Pond show deviating results (compared to Lake Kushu) regarding the lower electrical conductivity $(70 \mu \mathrm{S} / \mathrm{cm})$, temperature $\left(16.1^{\circ} \mathrm{C}\right)$, and oxygen saturation (76\%). With 9.3, the pH is as high as in Lake Kushu. The isotopic composition of $\delta^{18} \mathrm{O}_{\text {pond }}=-11 \%$, $\delta \mathrm{D}_{\text {pond }}=-72.6 \%$ and $d$ excess pond $=+15.6 \%$ plots above the GMWL which indicates that evaporation is negligible. The isotope composition of Himenuma Pond is rather low as compared to the Terney mean monthly precipitation and Lake Kushu water (Fig. 2c) and therefore indicates that recharge takes place mainly during the cold season. However, an isotope "amount effect" that indicates any dependency of oxygen isotopes from the precipitation amount is not visible in the Terney data. In general, Hime-numa Pond was characterised by a green algal bloom and a water transparency as low as in Lake Kushu $(<10 \mathrm{~cm})$. The lower temperature and oxygen saturation in comparison to Lake Kushu can be explained by the permanent cloud cover around Mt. Rishiri (1721 m) as noticed during fieldwork, reducing insolation and photosynthesis-induced bioproductivity. Due to the green algal bloom, the diatom diversity is low (6 taxa in surface water, 32 in surface sediment sample). The assemblage of the surface water sample consists of $A$. ambigua, reaching $97 \%$. A. ambigua represents the observed water parameters $(\mathrm{pH}=9.32$, eutrophic) very well. Further, other occurring taxa 
(e.g. C. neothumensis and $N$. lanceolata) in this assemblage are either trophy-tolerant or prefer eutrophic habitats (Van Dam et al., 1994; Krammer and Lange-Bertalot, 1997, 1999, 2000, 2004). In particular, S. hantzschii is associated with highly eutrophic conditions (Bennion et al., 1996). The presence of $S$. hantzschii in the surface sediment sample suggests higher nutrient concentration than in the past. Nevertheless, to provide a more detailed picture about the degree of past human influence further research is needed.

\subsection{Comparison to Kushu core diatom assemblages}

In comparison to the modern record, the fossil diatom assemblage of Lake Kushu is generally different. Only four species (R. gibba, P. brevistriata, S. pinnata, A. granulata) exceeding $5 \%$ of the assemblage occur both in the modern and fossil assemblages. Most significant changes are traceable in the diagram showing the reconstructed salinity (Fig. 9a). Here, the core assemblages between 1566.5 and $1169.5 \mathrm{~cm}$ (ca. 9-6.7 cal. kyr BP) indicate higher water salinity suggested by the appearance of brackish M. elliptica with a highest range in sample RK12-02-12_19-20, $P$. yarrensis and $R$. acuminata in sample RK12-02-16_16-17 and marine C. choctawhatcheeana, $C$. seiracanthus and $C$. radicans in sample RK12-02-14_7-8 (8.4 cal. kyr BP). S. pinnata reaches its maximum abundance (12\%) in sample RK12-02-14_7-8 $(1357.5 \mathrm{~cm})$, while $P$. brevistriata is most abundant in samples RK12-02-16_16-17 $(1566.5 \mathrm{~cm})$ and RK12-02-12_19-20 $(1169.5 \mathrm{~cm})$. P. brevistriata prefers weakly brackish conditions (Denys, 1990) and therefore indicates a transition from freshwater to brackish conditions in sample RK12-02 16_16-17 and from brackish to freshwater conditions in sample RK12-02 12_19-20. In contrast, S. pinnata is associated with brackish conditions (Denys, 1990) and shows highest abundance in sample RK12-02 14_7-8 together with the marine taxa. The shift towards freshwater, plankton-dominated assemblages $(B / P=0.1-0.45)$ starts with sample RK12-02-10_40-41 $(990.5 \mathrm{~cm})$ at ca. $5.8 \mathrm{cal}$. kyr BP. This could indicate a higher water level. However, the B/P does not only reflect the water level, but also the water transparency and nutrient concentrations and needs to be handled with care. Another main change is indicated in the diagram for trophic conditions (Fig. 9a). In comparison to the modern Lake Kushu samples, mesotraphentic A. ambigua (Reynolds, 1998; Poister et al., 2012) is replaced by highly eutraphentic $N$. palea and B. berolinensis (Bradshaw et al., 2002; Trobajo et al., 2009) indicating an increase in nutrient concentrations within the last $300 \mathrm{yr}$ BP.

The surface water sample from Hime-numa Pond shows highest similarity (high abundance of A. ambigua) compared to the sample RK12-02 01_1-2 from the Kushu core. Both samples represent a meso- to eutrophic freshwater lake. This leads to the assumption that the deforestation, sewage or remnants of formerly used fertilizers since the settlement on Rebun Island increased the nutrient inflow to Lake Kushu, resulting in hypereutrophic conditions. On the other hand, the well preserved natural forest belt on Rishiri Island (Müller et al., 2016) and the location of Hime-numa Pond above the coastal settlement belt have prevented a high level of pollution (as indicated for Lake Kushu) in the pond's catchment. It seems that settlement activities on Rebun Island played an important role in the eutrophication of Lake Kushu. These findings require further high-resolution analyses.

\subsection{Correlation to past climate and sea level changes}

A representative selection of fossil samples has been analysed to test the potential of using diatom analysis on the RK12 sediment core as a high-resolution archive of the post-glacial climate and environments as well as for the reconstruction of possible impact of sea water (long- and short-term events) on the Lake Kushu ecosystem with a special focus on the interval between the onset of the Jomon culture of northern Japan (ca. 14 kyr BP; Weber et al., 2013) and the present. The results of the pilot analysis presented here indicate significant changes throughout the RK12 core diatom assemblages, which should be correlated in detail with the regional and global-scale environmental changes.

Not only the diatom assemblage was used, but also selected sediment samples were geochemically analysed to detect potential environmental changes such as a varying impact of seawater throughout the RK12 core. Higher contents of $\mathrm{K}, \mathrm{Na}$, and $\mathrm{S}$ as well as elevated $\mathrm{Sr} / \mathrm{Ca}$ and $\mathrm{Mg} / \mathrm{Ca}$ are regarded as marine markers (Goff et al., 2004; Chagué-Goff, 2010; Chagué-Goff et al., 2012) and represent in the bulk sediment a potential marine influence. $\mathrm{Sr} / \mathrm{Ca}$ and $\mathrm{Mg} / \mathrm{Ca}$ ratios are known as salinity indicators from lake sediments (Gasse et al., 1987; Hoelzmann et al., 2010) and increasing salinity is here bound to an increasing marine influence. $P$ is interpreted as an indicator of productivity where higher $P$ values indicate more productive conditions under lacustrine conditions and diminished seawater influx. Si and Ti in the sediments may result from detrital input originating from suspended matter with higher values suggesting an increasing fluvial (riverine) influence.

\subsection{Marshy phase $16.6-10$ cal. kyr BP}

The sample RK12-02-19_82-83 $(1932.5 \mathrm{~cm})$ from the lowermost part of the analysed RK12 core (16.6 cal. kyr BP) represents the final phase of the Last Glacial Maximum (LGM). Studies of diatom-inferred climate reconstructions of the LGM are scarce in the Hokkaido region. However, pollen-based reconstructions dated the end of the LGM and the onset of deglaciation processes to 17 cal. kyr BP for this region (Igarashi et al., 2011). The lowermost sample is dominated by benthic freshwater D. subovalis (78\%) known as a common species in running waters (Krammer and Lange-Bertalot, 1997). P. viridis (15\%) is described as frequently occurring in a stream-fed pond at $50 \mathrm{~mm}$ water depth (Harper, 2010). Both, D. subovalis and $P$. viridis, might indicate a fluvial habitat which is characterised by ephemeral conditions.

The core sediments change from dark brown, organic-rich, partly laminated clay $(1930-1900 \mathrm{~cm})$ to brownish-olive to grey silty clay with intermediate pumiceous sand layers (1900$1650 \mathrm{~cm}$ ) suggesting a fluvial depositional environment (Einsele, 1992). The sediments show relatively high $\mathrm{Si}$ and Ti values that correspond to an increased detrital input under fluvial/deltaic environments. Such unstable environmental conditions for this phase are also reflected by varying values of the other parameters such as $\mathrm{Na}, \mathrm{P}$, and $\mathrm{K}$ concentrations as well as changing $\mathrm{Sr} / \mathrm{Ca}$ and $\mathrm{Mg} / \mathrm{Ca}$ ratios.

Diatom diversity and valve concentration are both relatively low in the lower core part, thus preclude a more detailed interpretation at this stage based on diatoms. However, the pilot results from the pollen analysis presented in Müller et al. (2016) will provide a chronology that shows significant changes, e.g. at the lateglacial/Holocene transition indicated by the shift from herbaceous to tree and shrub dominated vegetation.

\subsection{Brackish water lagoon phase 10-6.6 cal. kyr BP}

The rapid marine transgression in the early Holocene 8.5 to 6.5 cal. kyr BP (Omura and Ikehara, 2010) changed the fluvial/deltaic depositional environment and led to the formation of the palaeo-Kushu Bay (Sato et al., 1998). Initial occurrence of benthic brackish $M$. elliptica and $P$. yarrensis as well as the minor abundance of planktonic marine diatoms in RK12-16_16-17 at 9 cal. kyr BP indicate strong marine impact including first tidal influences. Increasing abundance of marine planktonic Chaetoceros spp. in 
RK12-02-14_7-8 suggests maximal marine impact at 8.4 cal. kyr BP (Figs. 8 and 9a). This corresponds with the geochemical composition of the RK12 core sediments. High $\mathrm{Na}, \mathrm{K}$, and $\mathrm{S}$ values together with increased $\mathrm{Sr} / \mathrm{Ca}$ and $\mathrm{Mg} / \mathrm{Ca}$ element ratios point to increased salinity as a result of the seawater influence. The detrital input of $\mathrm{Ti}$ and Si originating from fluvial suspended matter is decreasing and productivity (indicated by $\mathrm{P}$ content) is significantly lower around this time. This might correspond to the pronounced marine transgression associated with the " 8.2 k-event", an abrupt climate change in the northern hemisphere at $8.2 \mathrm{cal}$. kyr BP, first noted in Greenland ice core records (e.g. Alley and Ágústsdóttir, 2005; Thomas et al., 2007) caused by a meltwater pulse into the North Atlantic Ocean (Hijma and Cohen, 2010).

The diatom assemblage shows a decreasing marine influence in sample RK12-02-12_19-20 at ca. 6.7 cal. kyr BP with the significant decline in Chaetoceros spp., $P$. yarrensis and $R$. acuminata abundances. There is a time lag between the observed maximal marine impact in the RK12 core ( 8.4 cal. kyr BP) and that suggested by Sato et al. (1998) between 7.6 and 7 cal. kyr BP. Whether this time difference is due to the extracting location of the peat moor core at the southern margin of the basin (Kumano et al., 1990a) or to an imprecise or incorrect age model (Sato et al., 1998) remains open. Both scenarios seem to be plausible since the marine diatoms documented by Kumano et al. (1990a) are benthic diatoms suggesting that the area in the south was less influenced by marine tides compared to the RK12 core location and the age model published by Kumano et al. (1990a) is based only on four radiocarbon dates representing the ca. $16 \mathrm{~m}$ sediment core.

\subsection{Freshwater lake phase since $6.6 \mathrm{cal}$. kyr BP}

The transition from the lagoon phase towards a freshwater environment is marked by the decline of brackish/marine species and the occurrence of freshwater Aulacoseira spp. (Figs. 8 and 9a) suggesting a stable freshwater lake phase since $6.6 \mathrm{cal}$. kyr BP. Isochronously, the geochemical analysis shows lowering $\mathrm{Sr} / \mathrm{Ca}$ and $\mathrm{Mg} / \mathrm{Ca}$ ratios along with increasing $\mathrm{Si}$ and $\mathrm{Ti}$ contents between 1160 and $1050 \mathrm{~cm}$ suggesting the decrease of marine influence together with higher detrital input. Further, the low values of $\mathrm{S}$, $\mathrm{K}, \mathrm{Na}, \mathrm{Sr} / \mathrm{Ca}$, and $\mathrm{Mg} / \mathrm{Ca}$ and the higher $\mathrm{P}$, respectively, indicate reduced ion concentration of the lake water and increased productivity.

Evidence of the Late Holocene marine transgression reconstructed at several sites in eastern Hokkaido shortly before ca. 3 cal. kyr BP (Kumano et al., 1990b and references therein) was not yet found in the RK12 core. As the sample interval of our pilot study is coarse, this marine transgression affecting Lake Kushu might be detected with higher resolution analysis. At this stage, however, our results are in agreement with the maximum lake extension after the Holocene Climate Optimum (8.7-5.2 kyr BP) as postulated by Sato et al. (1998).

Due to the location of Rebun Island within a tectonically active zone, the question for short-term marine impact on Lake Kushu induced by tsunamis is of high interest. Sawai (2002) discovered dramatic changes in diatom assemblages from Lake Tokotan (Hokkaido) caused by tsunami impacts on Hokkaido. Potentially, tsunami events which affected the Rebun Island region should also be detectable in the RK12 core.

The palaeolimnology of Lake Kushu was likely controlled by several environmental factors, e.g. basin morphology, tsunami activities, the East Asian Monsoon system, and the global- and regional-scale sea level fluctuations that also had an influence on changes in the TWC as a main driver of the regional climate conditions. The TWC started influencing the climate in the southwestern
Hokkaido region in the Middle Holocene (Leipe et al., 2013; Nishida and Ikehara, 2013). The planned high-resolution analysis of the RK12 core material will provide an opportunity to get reliable information for reconstructing the palaeolimnology of Lake Kushu in more details.

\section{Conclusions}

In this pilot study the modern and fossil diatom assemblages from Lake Kushu and the surrounding environment have been studied. The samples taken in August 2014 represent a mature shallow freshwater lake, which is characterised by strong eutrophication in summer. This leads to a green algal bloom and to a decreased diversity and concentration of diatoms, especially in the surface water. The nutrient increase was most likely caused by the combination of a natural induced eutrophication process (flat basin topography, high productivity) and human activities (vegetation changes, pollution) during the settlement history of Rebun Island. The high wind energy caused by the East Asian Monsoon (May to November) initiate regular water turnover in the lake. Further sediment and water sampling from Lake Kushu and the surrounding area will facilitate the interpretation of the core diatom assemblages and help in understanding the limnological processes and diatom variability of this lake during the summer and the overturn spring and autumn periods.

We further tested the potential of the RK12 sediment core as a high-resolution archive to reconstruct past environmental and climate changes during the late-glacial and Holocene interval. The diatom assemblages and the geochemical sediment composition suggest that three substantially different environmental phases took place: (i) the Late Pleistocene marshy phase with unstable environments and higher detrital input (indicated by high Si and Ti values); (ii) the Early Holocene lagoon phase reflecting the post-glacial global sea level rise and corresponding marine transgression, as indicated by highest abundances of marine diatoms and increased $\mathrm{K}, \mathrm{Na}$, and $\mathrm{S}$ contents and corresponding $\mathrm{Sr} / \mathrm{Ca}$ and $\mathrm{Mg} / \mathrm{Ca}$ element ratios in the analysed samples; and (iii) the freshwater lake phase following the Holocene Climate Optimum.

This pilot study clearly shows that further high-resolution diatom and geochemical analyses of the sediments from the Lake Kushu core RK12 will be able to provide a very detailed (subdecadal to decadal) palaeolimnological record with an excellent age-control that will foster regional palaeoclimatic and palaeoenvironmental interpretations for the late-glacial and Holocene time interval and facilitate interpretation of the hunter-gatherer population dynamics and cultural sequences in the Hokkaido region.

\section{Acknowledgements}

We would like to acknowledge financial support from the Baikal-Hokkaido Archaeology Project (BHAP) founded by the Canadian Social Sciences and Humanities Research Council (SSHRC); project directors Prof. Andrzej Weber (University of Alberta, Canada) and Prof. Hirofumi Kato (Hokkaido University, Japan) for invitation and financial support of the field trip to Rebun Island and immense help during the fieldwork. We are thankful for the helpful comments of the two anonymous reviewers. The research of Mareike Schmidt is financed via a BHAP PhD stipend (University of Alberta, 0424634401). Pavel Tarasov's research is supported by the German Research Foundation (DFG) Heisenberg Program (Grant TA 540/5). We also thank the friendly Rebun islander who provided us with a small boat for water and diatom sampling on Lake Kushu. 


\section{References}

Alley, R.B., Ágústsdóttir, A.M., 2005. The 8k event: cause and consequences of a major Holocene abrupt climate change. Quatern. Sci. Rev. 24, 1123-1149.

Anonymous, 2001. DIN EN 13346, April 2001. Charakterisierung von Schlämmen Bestimmung von Spurenelementen und Phosphor - Extraktionsverfahren mit Königswasser; Deutsche Fassung EN 13346: 2000, Beuth Verlag (Ed.).

Battarbee, R.W., Jones, V.J., Flower, R.J., Cameron, N.G., Bennion, H., Carvalho, L., Juggins, S., 2001. Diatoms. In: Smol, J.P., Birks, H.J.B., Last, W.M. (Eds.), Tracking Environmental Change Using Lake Sediments, Terrestrial, Algal, and Siliceous Indicators, vol. 3. Kluwer Academic Publishers, Dordrecht, pp. 155-202.

Bennion, H., Juggins, S., Anderson, N.J., 1996. Predicting epilimnetic phosphorus concentrations using an improved diatom-based transfer function and its application to Lake Eutrophication management. Environ. Sci. Technol. 30, 2004-2007.

Bradshaw, E., Anderson, N.J., Jensen, J.P., Jeppesen, E., 2002. Phosphorus dynamics in Danish lakes and the implications for diatom ecology and palaeoecology. Freshwat. Biol. 47, 1963-1975.

Chagué-Goff, C., 2010. Chemical signatures of palaeotsunamis: a forgotten proxy? Mar. Geol. 271, 67-71.

Chagué-Goff, C., Andrew, A., Szczucinski, W., Goff, J., Nishimura, Y., 2012. Geochemical signatures up to the maximum inundation of the 2011 Tohokuoki tsunami - implications for the 869 AD Jogan and other paleotsunamis. Sediment. Geol. 282, 65-77.

Craig, H., 1961. Isotopic Variations in Meteoric Waters. Sci., New Ser. 133, 17021703.

De Vries, J.L., Vrebos, B.A.R., 2002. Quantification of infinitely thick specimens by XRF analysis. In: Van Grieken, R.E., Markowicz, A.A. (Eds.), Handbook of X-ray Spectrometry, second ed. Marcel Dekker Inc., New York, Basel, pp. 341-406.

Denys, L., 1990. Fragilaria Blooms in the Holocene of the Western Coastal Plain of Belgia. In: Simola, H. (Ed.), Proceedings of the Tenth International DiatomSymposium - Joensuu, Finland 1988. Koeltz-Scientific Books, Koenigstein, pp. 397-406.

Deryugin, V.A., 2008. The metal ages and medieval period. Archaeol. Ethnol. Anthropol. Eurasia 33, 58-66.

Einsele, G., 1992. Sedimentary Basins. Evolution, Facies and Sediment Budget. Springer Verlag, Berlin, Heidelberg.

ESRI, 2014. ArcGIS Desktop: Release 10.2. Environmental Systems Research Institute, Redlands, CA.

Gasse, F., 1986. East African diatoms - taxonomy, ecological distribution. Bibliotheca Diatomologica, vol. 11. J. Cramer, Berlin.

Gasse, F., Fontes, J.C., Plaziat, J.C., Carbonel, P., Kaczmarska, I., De Dekker, P., 1987. Biological remains, geochemistry and stable isotopes for the reconstruction of environmental and hydrological changes in the Holocene lakes from North Sahara. Palaeogeogr. Palaeoclimatol. Palaeoecol. 60, 1-46.

Geospatial Information Authority of Japan, 2012. Topographic map Funadomari $1: 25,000$.

Goff, J.R., Wells, A., Goff, C., Nichol, S.L., Devoy, R.J.N., 2004. The elusive AD 1826 Tsunami, South Westland, New Zealand. NZ Geogr. 60, 28-39.

Göke, G., 1993. Einführung in die Präparation der Diatomeen. Naturwissenschaftliche Vereinigung Hagen e.V. Sonderheft SM 1.

Gómez, N., Riera, J.L., Sabater, S., 1995. Ecology and morphological variability of Aulacoseira granulata (Bacillariophyceae) in Spanish reservoirs. J. Plankton Res. $17,1-16$.

Goslar, T., van der Knaap, W.O., Kamenik, C., van Leeuwen, J.F.N., 2009. Free-shape ${ }^{14} \mathrm{C}$ age-depth modelling of an intensively dated modern peat profile. J. Quatern. Sci. 24, 481-499.

Gotanda, K., Nakagawa, T., Tarasov, P.E., Kitagawa, J., Inoue, Y., Yasuda, Y., 2002. Biome classification from Japanese pollen data: Application to modern-day and Late Quaternary samples. Quatern. Sci. Rev. 21, 647-657.

Gotanda, K., Nakagawa, T., Tarasov, P.E., Yasuda, Y., 2008. Disturbed vegetation reconstruction using the biomization method from Japanese pollen data: modern and Late Quaternary samples. Quatern. Int. 184, 56-74.

Goto, Y., McPhie, J., 1998. Endogenous growth of a Miocene submarine dacite cryptodome, Rebun Island, Hokkaido, Japan. J. Volcanol. Geoth. Res. 84, $273-$ 286.

Grimm, E.C., 1991-2011. Tilia ${ }^{\circledR} 1.7 .16^{\circledR}$ [Computer Software] Illinois State Museum, Research and Collection Center, Springfield.

Guiry, M.D., Guiry, G.M., 2015. AlgaeBase. World-wide Electronic Publication. National University of Ireland, Galway. Accessible via: <http://www.algaebase. org>.

Hamano, Y., Maeda, Y., Matsumoto, Y., Kumano, S., 1985. Holocene sedimentary history of some coastal plains in Hokkaido, Japan. III. Transition of diatom assemblages in Tokoro along the Okhotsk Sea. Jpn. J. Ecol. 35, 307-316.

Hase, Y., Iwauchi, A., Uchikoshiyama, U., Noguchi, E., Sasaki, N., 2012. Vegetation changes after the late period of the Last Glacial Age based on pollen analysis of the northern area of Aso Caldera in central Kyushu, Southwest Japan. Quatern. Int. 254, 107-117.

Hashimoto, M., 1991. Geology of Japan. Terra Scientific Publishing Company, Kluwer Academic Publishers, Tokyo, Dordrecht.

Harper, M.A., 2010. Migration rhythm of the benthic diatom Pinnularia viridis on pond silt (note). N.Z. J. Mar. Freshwat. Res. 10, 381-384.

Hijma, M.P., Cohen, K.M., 2010. Timing and magnitude of the sea-level jump preluding the 8.2 kiloyear event. Geology 38 (3), 275-278.
Hijmans, R.J., Cameron, S.E., Parra, J.L., Jones, P.G., Jarvis, A., 2005. Very high resolution interpolated climate surface for global land areas. Int. J. Climatol. 25, 1965-1978.

Hoelzmann, P., Schwalb, A., Roberts, N., Cooper, P., Burgess, A., 2010. Hydrological response of an east-Saharan palaeolake (NW Sudan) to early-Holocene climate. The Holocene 20, 537-549.

Houk, V., Klee, R., Tanaka, H., 2010. Atlas of freshwater diatoms with a Brief Key and Descriptions, Part III: Stephanodiscaceae A, Cyclotella, Tertiarius, Discostella. In: Poulíčková, A. (Ed.), Fottea 10 (Supplement). Czech Phycological Society, Prague.

IAEA, 2015. Global Network of Isotopes in Precipitation. The GNIP database. Accessible via: <http://www-naweb.iaea.org/napc/ih/index.html>.

Igarashi, Y., 2013. Holocene vegetation and climate on Hokkaido Island, northern Japan. Quatern. Int. 290-291, 139-150.

Igarashi, Y., Yamamoto, M., Ikehara, K., 2011. Climate and vegetation in Hokkaido, northern Japan, since the LGM: Pollen records from core GH02-1030 off Tokashi in the northwestern Pacific. J. Asian Earth Sci. 40, 1102-1110.

Ihira, M., Maeda, Y., Matsumoto, E., Kumano, S., 1985. Holocene sedimentary history of some coastal plains in Hokkaido, Japan. II. Diatom assemblages of the sediments from Kushiro Moor. Jpn. J. Ecol. 35, 199-205.

Jarvis, A., Reuter, H.I., Nelson, A., Guevara, E., 2008. Hole-filled Seamless SRTM Data V4. International Centre for Tropical Agriculture (CIAT).

Jenkins, R., 1999. X-ray Fluorescence Spectrometry, second ed. Wiley \& Sons, New York.

Kalbe, L., 1980. Kieselalgen in Binnengewässern. Die neue Brehm-Bücherei Wittenberg Lutherstadt.

Kigoshi, T., Kumon, F., Hayashi, R., Kuriyama, M., Yamada, K., Takemura, K., 2014 Climate changes for the past 52 ka clarified by total organic carbon concentrations and pollen composition in Lake Biwa, Japan. Quatern. Int. 333 $2-12$.

Kimura, G., 1997. Cretaceous episodic growth of the Japanese Islands. The Island Arc 6, 52-68.

Kobayasi, H., Idei, M., Nagumo, T., Mayama, S., Osada, K., 2006. H. Kobayasi's Atlas of Japanese Diatoms based on electron microscopy, vol. 1. Uchida Rokakuho Publishing Co., Ltd., Tokyo (in Japanese).

Krammer, K., Lange-Bertalot, H., 1997. Bacillariophyceae. 1. Teil: Naviculaceae. In: Ettl, H., Gerloff, J., Heynig, H., Mollenhauer, D. (Eds.), Süßwasserflora von Mitteleuropa 2/1. Spektrum Akademischer Verlag, Heidelberg.

Krammer, K., Lange-Bertalot, H., 1999. Bacillariophyceae. 2. Teil: Bacillariaceae Epithemiaceae, Surirellaceae. In: Ettl, H., Gerloff, J., Heynig, H., Mollenhauer, D. (Eds.), Süßwasserflora von Mitteleuropa 2/2. Spektrum Akademischer Verlag, Heidelberg.

Krammer, K., Lange-Bertalot, H., 2000. Bacillariophyceae. 3. Teil: Centrales, Fragilariaceae, Eunotiaceae. In: Ettl, H., Gerloff, J., Heynig, H., Mollenhauer, D. (Eds.), Süßwasserflora von Mitteleuropa 2/3. Spektrum Akademischer Verlag, Heidelberg.

Krammer, K., Lange-Bertalot, H., 2004. Bacillariophyceae. 4. Teil: Achnanthaceae Kritische Ergänzungen zu Achnanthes s. 1., Navicula s. str., Gomphonema. In: Ettl, H., Gerloff, J., Heynig, H., Mollenhauer, D. (Eds.), Süßwasserflora von Mitteleuropa 2/4. Spektrum Akademischer Verlag, Heidelberg.

Kuritani, T., Nakamura, E., 2006. Elemental fractionation in lavas during posteruptive degassing: evidence from trachytic lavas, Rishiri Volcano, Japan. J. Volcanol. Geoth. Res. 149, 124-138.

Kumano, S., Sekiya, K., Maeda, Y., 1984. Holocene sedimentary history of some coastal plains in Hokkaido, Japan. I. Diatom assemblages of the sediments from Kutcharo Lake. Jpn. J. Ecol. 34, 389-396.

Kumano, S., Kuromi, M., Maeda, Y., Matsumoto, E., Nakamura, T., Matsushima, Y., Sato, H., 1990a. Holocene sedimentary history of some coastal Plains in Hokkaido, Japan, V. sedimentary history of Kushu Lake and Akkeshi. Ecol. Res. 5, 277-289.

Kumano, S., Ihira, M., Maeda, A., Yamauchi, M., Matsumoto, E., Matsuda, I., 1990b. Holocene sedimentary history of some coastal plains in Hokkaido, Japan, IV. Diatom assemblages in the sediments from Kushiro Moor (2). Ecol. Res. 5, 221 235.

Lee, J.H., 2011. Algal Flora of Korea, Vol. 3, No. 5. Marine Diatoms I: Chrysophyta: Bacillariophyceae: Centrales: Biddulphiineae: Chaetoceraceae. National Institute of Biological Resources, Korea.

Lee, J.H., 2012. Algal Flora of Korea, Vol. 3, No. 6. Marine Diatoms II: Chrysophyta: Bacillariophyceae: Centrales: Thalassiosiraceae: Rhizosoleniaceae. National Institute of Biological Resources, Korea.

Leipe, C., Kito, N., Sakaguchi, Y., Tarasov, P.E., 2013. Vegetation and climate history of northern Japan inferred from the 5500-year pollen record from the Oshima Peninsula, SW Hokkaido. Quatern. Int. 290-291, 151-163.

Levkov, Z., 2009. Amphora senso lato. In: Lange-Bertalot, H. (Ed.), Diatoms of Europe, vol. 5. A.R.G. Gantner K.G., Ruggell.

Lynch, J., 1990. Provisional elemental values for eight new geochemical lake sediment and stream sediment reference materials LKSD-1, LKSD-2, LKSD-3, LKSD-4, STSD-1, STSD-2, STSD-3 and STSD-4. Geostandards Newslett. 14 (1), $153-167$.

Mandal, A.K., Zhang, J., Asai, K., 2011. Stable isotopic and geochemical data for inferring sources of recharge and groundwater flow on the volcanic island of Rishiri, Japan. Appl. Geochem. 26, 1741-1751.

METI and NASA (Ministry of Economy, Trade and Industry, Japan, and National Aeronautics and Space Administration), 2011. Advanced Spaceborne Thermal Emission and Reflection Radiometer: Global Digital Elevation Model 
Version 2. <http://www.jspacesystems.or.jp/ersdac/GDEM/E/4.html> (accessed 22.12.15).

Meyer, H., Schönicke, L., Wand, U., Hubberten, H.-W., Friedrichsen, H., 2000. Isotope studies of hydrogen and oxygen in ground ice - experiences with the equilibration technique. Isot. Environ. Health Stud. 36, 133-149.

Moiseyev, V.G., 2008. On the origin of the Okhotsk population of Northern and Eastern Hokkaido: cranial evidence. Archaeol. Ethnol. Anthropol. Eurasia 33 134-141.

Morales, E.A., Guerrero, J.M., Wetzel, C.E., Sala, S., Ector, L., 2013. Unraveling the identity of Fragilaria pinnata Ehrenberg and Staurosira pinnata Ehrenberg: research in progress on a convoluted story. Cryptogamie, Algologie 34, 89-102.

Müller, S., Schmidt, M., Kossler, A Leipe, C, Irino, T, Yamamoto, M., Yonenobu, $\mathrm{H}_{\text {, }}$ Goslar, T., Kato, H., Wagner, M., Weber, A.W., Tarasov, P.E., 2016. Palaeobotanical records from Rebun Island and their potential for improving the chronological control and understanding human-environment interactions in the Hokkaido Region, Japan. The Holocene 26 (10) (in press).

Nakagawa, T., 2007. Double-L channel: an amazingly non-destructive method of continuous sub-sampling from sediment cores. Quatern. Int. 167-168, 298.

Nakagawa, T., Tarasov, P.E., Nishida, K., Gotanda, K., Yasuda, Y., 2002. Quantitative pollen-based climate reconstruction in central Japan: application to surface and Late Quaternary spectra. Quatern. Sci. Rev. 21, 2099-2113.

Nakagawa, T., Kitagawa, H., Yasuda, Y., Tarasov, P.E., Gotanda, K., Sawai, Y., 2005. Pollen/event stratigraphy of the varved sediment of Lake Suigetsu, central Japan from 15,701 to 10,217 vyr BP (Suigetsu varve years before present): Description, interpretation, and correlation with other regions. Quatern. Sci. Rev. 24, 1691 1701.

Nishida, N., Ikehara, K., 2013. Holocene evolution of depositional processes off southwest Japan: response to the Tsushima Warm Current and sea-level rise. Sediment. Geol. 290, 138-148.

Ogi, M., Tachibana, Y., Yamazaki, K., 2004. The connectivity of the Winter North Atlantic Oscillation (NAO) and the Summer Okhotsk High. J. Meteorol. Soc. Jpn. 82, 905-913.

Ohyi, $\mathrm{H}$, 1975. The Okhotsk culture, a maritime culture of the Southern Okhotsk se region. In: Fitzhugh, W. (Ed.), Prehistoric Maritime Adaptations of the Circumpolar Zone. De Gruyter, Netherlands.

Ohtsuka, T., 2002. Checklist and illustration of diatoms in the Hii River. Diatoms 18, 23-56.

Omura, A., Ikehara, K., 2010. Deep-sea sedimentation controlled by sea-level rise during the last deglaciation, an example from the Kumano Trough, Japan. Mar Geol. 274, 177-186.

Poister, D., Kurth, A., Farrell, A., Gray, A., 2012. Seasonality of Aulacoseira ambigua abundance and filament length: biogeochemical implications. Plankton Benthos Res. 7, 55-63.

Reimer, P.J., Bard, E., Bayliss, A., Beck, W.J., Blackwell, P.G., Bronk Ramsey, C., Buck, C. E., Cheng, H., Edwards, R.L., Friedrich, M., Grootes, P.M., Guilderson, T.P., Hafidason, H., Hajdas, I., Hattè, C., Heaton, T.J., Hoffmann, D.L., Hogg, A.G. Hughen, K.A., Kaiser, K.F., Kromer, B., Manning, S.W., Niu, M., Reimer, R.W., Richards, D.A., Scott, E.M., Southon, J.R., Staff, R.A., Turney, S.M., Van der Plicht, J., 2013. IntCal13 and Marine13 radiocarbon age calibration curves 0-50,000 years cal BP. Radiocarbon 55, 1869-1887.

Reuter, H.I., Nelson, A., Jarvis, A., 2007. An evaluation of void filling interpolation methods for SRTM data. Int. J. Geogr. Inform. Sci. 21, 983-1008.

Reynolds, C.S., 1998. What factors influence the species composition of phytoplankton in lakes of different trophic status? Hydrobiologia 369 (370), $11-26$.

Round, F.E., Crawford, R.M., Mann, D.G., 1990. The Diatoms, Biology \& Morphology of the Genera. Cambridge University Press, Cambridge.

Rozanski, K., Johnson, S.J., Schotterer, U., Thomson, L.G., 1997. Reconstruction of past climates from stable isotope records of palaeo-precipitation preserved in continental archives. Hydrol. Sci. J. 42, 725-745.

Sato, H., Kumano, S., Maeda, Y., Nakamura, T., Matsuda, I., 1998. The Holocene development of Kushu Lake on Rebun Island in Hokkaido, Japan. J. Paleolimnol. 20, 57-69.

Sawai, Y., 2002. Evidence for 17th century tsunamis generated on the KurilKamchatka subduction zone, Lake Tokotan, Hokkaido, Japan. J. Asian Earth Sci. 20, 903-911.

Schönborn, W., Risse-Buhl, U., 2013. Lehrbuch der Limnologie, second ed Schweizerbart, Stuttgart.

Smol, J.P., Stoermer, E.F., 2010. The Diatoms: Applications for the Environmental and Earth Sciences, second ed. Cambridge University Press, Cambridge.

Tanaka, H., 2014. Atlas of Freshwater Fossil Diatoms in Japan - Including related Recent Taxa. Uchida Rokakuho Publishing Co., Ltd., Tokyo (in Japanese).

Tarasov, P.E., Nakagawa, T., Demske, D., Österle, H., Igarashi, Y., Kitagawa, J., Mokhova, L., Bazarova, V., Okuda, M., Gotanda, K., Miyoshi, N., Fujiki, T.
Takemura, Yonenobu, H., Fleck, A., 2011. Progress in the reconstruction of Quaternary climate dynamics in the Northwest Pacific: A new analogue reference dataset and its application to the 430-kyr pollen record from Lake Biwa. Earth Sci. Rev. 10, 64-79.

Terry, J.P., Feng, C.-C., 2010. On quantifying the sinuosity of typhoon tracks in the western North Pacific basin. Appl. Geogr. 30, 678-686.

Thomas, E.R., Wolff, E.W., Mulvaney, R., Steffensen, J.P., Johnsen, S.J., Arrowsmith, C., White, J.W.C., Vaughn, B., Popp, T., 2007. The 8.2ka event from Greenland ice cores. Quatern. Sci. Rev. 26, 70-81.

Trobajo, R., Clavero, E., Chepurnov, V.A., Sabbe, K., Mann, D.G., Ihihara, S., Cox, E.J., 2009. Morphological and mating diversity within the widespread bioindicator Nitzschia palea (Bacillariophyceae). Phycologia 48, 443-459.

Tuji, A., Kawashima, A., Julius, M.L., Stoermer, E.F., 2003. Stephanodiscus akanensis sp. nov., a new species of extant diatom from Lake Akan, Hokkaido, Japan. Bull. Natl. Sci. Mus. Tokyo, Ser. B 29, 1-8.

Van Dam, H., Mertens, A., Sinkeldam, J., 1994. A coded checklist and ecological indicator values of freshwater diatoms from the Netherlands. Netherlands J. Aquat. Ecol. 28, 117-133.

Weber, A., Jordan, P., Kato, H., 2013. Environmental change and cultural dynamics of Holocene hunter-gatherers in Northeast Asia: comparative analyses and research potentials in Cis-Baikal (Siberia, Russia) and Hokkaido (Japan). Quatern. Int. 290-291, 3-20.

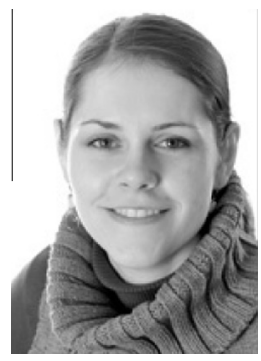

Mareike Schmidt is a second year PhD student and research associate at the Institute of Geological Sciences of the Freie Universität Berlin. Her work is supported by a PhD stipend from the international "Baikal-Hokkaido Archaeology Project" (BHAP: http://bhap.artsrn.ualberta.ca/) granted by the Social Science and Humanities Research Council of Canada via the University of Alberta. The key aim of her current project is to reconstruct local and regional environments of the northwest Hokkaido Region since ca. 17 kyr BP to present, using diatom analysis applied to the RK12 sediment core from Lake Kushu.

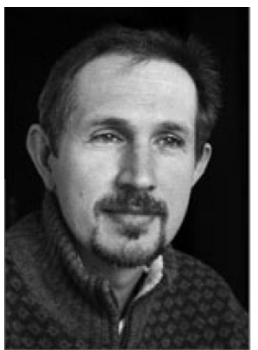

Pavel E. Tarasov is a Professor in Quaternary Sciences, an international expert in Late Quaternary vegetation and climate history of northern Eurasia, at the Institute of Geological Sciences, Freie Universität Berlin. He is one of the Principal Investigators in the Baikal-Hokkaido Archaeology Project and leads research on palaeobotany, palaeoclimatology and human-environment interactions.

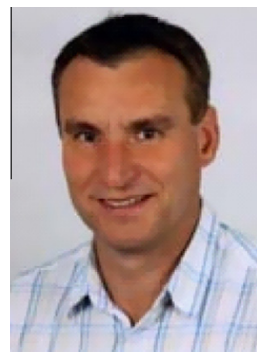

Philipp Hoelzmann is a Senior Scientist and Head of the Physical Geography Laboratory at the Freie Universität Berlin which is equipped for sedimentological, geochemical, geophysical, mineralogical and environmental investigations. His expertise is primarily in the analysis of (lake) sediments from Europe, Africa, Central Asia and Central America. The assembled data is used for lakelevel and palaeoclimate reconstructions as well as environmental geochemical and archaeological research. 


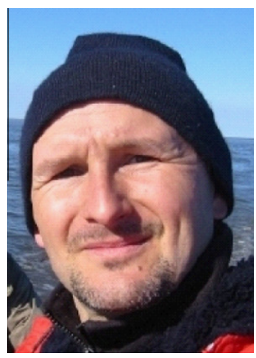

Hanno Meyer is a Senior Scientist and Head of the Stable Isotope Laboratory at the Alfred Wegener Institute Helmholtz Centre for Polar and Marine Research in Potsdam. His research is focused on the climate reconstruction with stable isotope analysis especially in the Polar Regions across the world as well as in the permafrost regions.

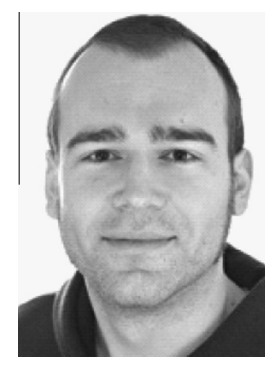

Christian Leipe is a Scientific Associate (founded by the German Research Foundation, DFG) at the Institute of Geological Sciences at the Freie Universität Berlin. His expertise focusses on the analysis of vegetation and biome reconstruction (Quaternary) in monsooninfluenced regions in Asia. 